Article

\title{
A Taxonomic Analysis of Smart City Projects in North America and Europe
}

\author{
Guido Perboli $1,2,3, *(1)$ and Mariangela Rosano 1,2 (1) \\ 1 Center for Automotive Research and Sustainable Mobility-CARS@Polito, Politecnico di Torino, \\ 10129 Turin, Italy; mariangela.rosano@polito.it \\ 2 ICT for City Logistics and Enterprises Center-ICELab@Polito, Politecnico di Torino, 10129 Turin, Italy; \\ 3 CIRRELT, Pavillon André-Aisenstadt, Montreal, QC H3T 1J4, Canada \\ * Correspondence: guido.perboli@polito.it
}

Received: 12 July 2020; Accepted: 30 July 2020; Published: 22 September 2020

check for updates

\begin{abstract}
In recent years, the concept of a "Smart City" became central in the agenda of researchers, practitioners, and stakeholders. Although the application of information and communication technologies on city management has advanced exponentially, also other components would be needed for building a truly sustainable urban environment. Researchers from different domains debated the definition of a smart city and the conceptual variants. However, a broad view of the smart city field is still missing. This paper attempts to fill this gap by proposing a taxonomic classification of the most 105 outstanding smart city projects in Europe and North America. Collected data are then processed by statistical tools for clearly highlighting the success factors, trends and future paths in which all these projects are moving, along with different aspects (e.g., business model, purpose, industry). We then investigate the European and the North American Smart City concepts, illustrating the key role of mixed public and private partnerships in creating successful projects and the focus on the urban transportation, and freight and last-mile delivery in particular. Moreover, it emerges how the business modeling and the exploitation aspects have still low integration in the projects.
\end{abstract}

Keywords: smart cities; smart city projects; taxonomy; business models

\section{Introduction}

The world urbanization prospect highlights that by 2030, urban areas were projected to house $60 \%$ of people [1]. Establishing smart cities is identified by the policymakers as the next stage in urbanization, improving the quality of life for residents of the cities, increasing the efficiency and attractiveness, while minimizing the environmental impact. Understanding the key characteristics and trends of smart cities becomes crucial to the implementation of the agendas for the sustainable development and inclusive growth of urban areas, in different countries. The literature concerning the concept of the smart city is vast. However, a commonly accepted definition is still missing. Indeed, all the contributions rely on restricted facets of the city management (e.g., the adoption of technologies for urban mobility), without a holistic vision of smart cities. Moreover, concerning the Smart City Projects (SCPs) already developed, we identify a lack of a structured and repeatable method by recognized entities for categorizing SCPs and gathering the related information about results and lessons learned. Thus, to our vision in the literature and the state-of-the-art, a broad view of smart city initiatives is missing.

This lack makes difficult the identification of the key success factors of smart city initiatives and how they vary according to geographical and socio-politic patterns. Therefore, this paper has different goals and contributions. First, we present a repeatable methodology based on a taxonomy to classify SCPs with an interdisciplinary view, using a series of keywords/axes that reflect the heterogeneous 
nature of a smart city. Second, thanks to the structured data collected by the taxonomy, we apply a statistical analysis over the data, providing a global view of the smart city concept, and identifying the current trend and future path with emphasis on what European and North American communities define as a smart city. This is, to our knowledge, the first comparison of two of the most important and vibrant markets both for practitioners and academics in Smart Cities. Thus, understanding how the stakeholders, the policy-makers and the project managers behave and the differences in objectives and project implementation is crucial to develop, in the near future, a true sustainable society. These contributions make the paper useful to: (i) researchers and academics to introduce the subject comprehensively and investigate possible research lines; (ii) managers and public entities to deploy new strategies.

The paper has the following section. In Section 2, we conduct a literature review concerning the concept of "Smart City". We introduce a taxonomy for SCPs, considering in it the different aspects, including business model, purpose, industry, tools, objectives, funding scheme, and stakeholders in Section 3. Section 4 applies the taxonomy to 105 outstanding European and North American SCPs, to determine similitude and difference in defining a smart city. Finally, Section 5 reports some conclusions. To our knowledge, this study provides the most extensive analysis of SCPs presented in the literature.

\section{Literature Review}

By 2050, the continuing population growth forecast to add 2.5 billion people to the world's population most of them will inhabit cities. According to estimations provided by the United Nations [1], today the most urbanized regions include Northern America (82\% living in urban areas in 2014), Latin America and the Caribbean (80\%), and Europe (73\%). With demographic growth and urbanization correspond an increase in demand for resources, and sustainable development challenges are arising in cities and communities. Smart cities have attracted considerable interest from industry, local administrations and researchers, as a response to the unsustainable resources use and management, and more in general to the healthy and sustainable growth of the city from different standpoints (i.e., environment, economy). As stated in the introduction and confirmed by the literature, although the smart city concept gains attention and popularity, there is still confusion about the meaning of this term. Different contributions in literature are devoted to investigating the many definitions of a smart city that exist and the conceptual variants obtained by replacing the term "smart" with alternative adjectives, as "intelligent", "digital", "cyber", "informational", and "wired" [2-11]. For example, a paper [2] identified a list of more than 20 definitions of a smart city. Other authors [12] clustered the various views to the building of smart cities, proposing a framework that includes restrictive, reflective, rationalistic and critical schools of thought. The paper by Borsekova et al. [13] focuses on the concept of a smart city and its specific components in relation to the size of the city. Within the different definitions of a smart city, a consistent part of the literature is focused on the proposing Information and Communication Technology (ICT) solutions in smart cities, using, for example, big data analytics [14-16].

In particular, some authors [17] stated that technology helps the city to develop a smart approach to designing urban policies and fostering citizen participation. Other frameworks propose different methodologies, including taxonomies, for the measurement "smartness" and the smart city categorization. In 2016, some authors [18] reviewed existing smart city conceptualization and benchmarking methods, and synthesize them into a unified smart city model. The paper by Lee et al. [19] proposes a conceptual framework to lay out a holistic taxonomy for analysing smart city development and implementation practices. The notion of the smart city through a taxonomy of relevant application domains (i.e., natural resources and energy, transport and mobility, buildings, living, government, and economy and people) has been also investigated [20]. Lazaroiu and Roscia [21] propose a fuzzy logic based model for evaluating the smart cities, under the established objectives. Moreover, they apply this model to the evaluation of different cities in Italy. Benjelloun et al. [22] 
proposes the first attempt of taxonomy focusing on City Logistics projects, but without considering the other aspects of SCPs, including social inclusion, business and governance models, human and social relations. Some authors [23] suggest another action taxonomy under the smart city topic, but strictly related to the smart mobility initiatives. Another work [24] provided an operational definition of the smart cities in Europe, supported by qualitative evidence on the correlations between the dimensions of smartness and a measure of wealth. Finally, the paper by Silva et al. [25] presented an overview of smart cities discussing features and characteristics, generic architecture, composition, and real-world implementations of smart cities. In particular, the authors provided a wider vision of a smart city compared to the previous contributions in the literature, identifying four pillars: institutional, physical, social and economic infrastructures. However, this contribution is still too focused on the technical details of smart city, disregarding the stakeholder involvement and the managerial aspects. Indeed, it described the generic architecture of a smart city as a system composed by four layers, i.e., sensing layer, transmission layer, data management layer, and application layer, which facilitate interoperability among the various subsystems to improve the quality of life of urban citizens.

To our vision, just a little has been done to give a holistic vision of the topic and to classify existing SCPs. In fact, the methodologies and taxonomies proposed are focused on particular and restricted aspects of the smart city (i.e., only on the application domains or even more stringent, on transportation $[22,23])$, and on a specific geographic area $[6,19,24,26]$. Thus, all these contributions do not consider a fully-comprehensive vision of smart cities and a lack of a structured method for categorizing SCPs and gather the related information, emerges. Moreover, Birbi and Krogstie [27] identified in their interdisciplinary literature review a gap in the research within the field of smart sustainable cities, concerning the several urban domains where smart solutions can have substantial contributions in relation to sustainability, while literature and cities still focus mainly on infrastructure for urban metabolism. The authors encouraged in-depth research on smart sustainable cities, especially applied theoretical investigations, thorough qualitative analyses, and empirical studies focused on establishing, uncovering, and substantiating the assumptions underlying the smart city [27].

We aim to overcome these gaps, proposing a more comprehensive taxonomy of smart cities projects. We then use the taxonomy to show a picture of the smart city visions in Europe and North America. In the literature, there is another contribution to the smart city concept applied to Europe and North America [28]. However, first it is based on a relatively smaller sample of projects (32 empirical case studies) and second, it is focused on identifying five tensions between the smart city and the sustainability, disregarding a wider vision. Before to go into the details of the taxonomy and its application, we conclude the remaining part of this section, analysing the literature on smart cities, with more emphasis on our two main geographical targets. In particular, we conduct a literature review to explore what European and North American scientific communities understand as "Smart City" and if common visions or different understating and knowledge are present in the two areas. In doing so, we analysed the most recent literature from 2000 to 2018 published in different sources, like scientific journals, conferences proceedings, textbooks, doctoral dissertations and documents by municipalities, recognized companies and associations to obtain data of SCPs. We referred to the Scopus bibliographic database for our analysis because it contains articles from all major journals dealing with transportation. Many journals are also recognized by the ERA 2012 Journal List evaluation across eight discipline clusters [29]. Then, we adopted a keyword extraction approach [30] to select the most significant and representative words present in the definition. Table 1 includes the different definitions of the smart city respectively in European and North American projects. These definitions highlight as in general, the concept of smart city considers the adoption of new technologies and data to solve and manage challenges related to the cities development as liveability, mobility, sustainability, and economic growth, in an efficient way. Figures 1 and 2 show the most frequent keywords and related percentages, respectively in the European and North American literature concerning smart cities. Comparing the keywords from the European perspective and the specific one for North America, it is possible to conclude that Canada and United States are aligned with the European concept, 
since the keywords and the relative percentages are similar to the general concept. Indeed, in both the parties, $83 \%$ of the definitions involve the adoption of digital tools, big data or ICTs. A second key concept characterizing many definitions is their underlying emphasis on people and social $(61 \%$ in Europe and $67 \%$ in North America). More in detail, smart city definitions include the concepts of social and cultural development [5], education and social learning [31-34], social sustainability [35] and citizens engagement and inclusion. Moreover, according to some authors [20,24,36], a smart city is a mean of enhancing the quality of life of citizens, which represents another important keyword in the literature (44\% in Europe and 50\% in North America). Figure 1 highlights that the European concept of the smart city is often related (50\% of definitions) to the environment and natural resources, and their sustainability. The Horizon 2020 programme also fosters this high interest in environmental sustainability, resource efficiency, and ecosystems. Nonetheless, it is relevant to highlight the weight that Canadian definitions give to the interconnection and the governance. Indeed, several American definitions and projects are drawing the attention to the fundamental support that partnerships and synergies represent for the successful development of smart communities. Comparing the results obtained in our sample of contributions, we highlight a higher propensity of American SCPs to include a business and entrepreneurship perspective ( $44 \%$ of studies compared to $39 \%$ in Europe). Although, also in Europe this interest is growing, according to Hollands [5] North American cities have always been more shaped by pro-business influences, while European cities have historically been more welfare-oriented in their urban policy-making and social inclusion. Since a holistic definition of a smart city and an official institution that regulates the recent smartness trend do not exist, different contributions in literature debate on the future of smart cities. For example, a work [5] provides a preliminary critical polemic against some of the more rhetorical aspects of smart cities. Moreover, other authors [6] state that technology may be perceived as a panacea and smart initiatives may be isolated and episodic experiments. To our vision, although different taxonomies are proposed, they lack in gathering data and information about SCPs, their success factors, and their environmental contexts and complexity of the city. This lack affects the benchmarking of initiatives in different countries and the smart city assessment that must take into account that cities have different visions and priorities [2].

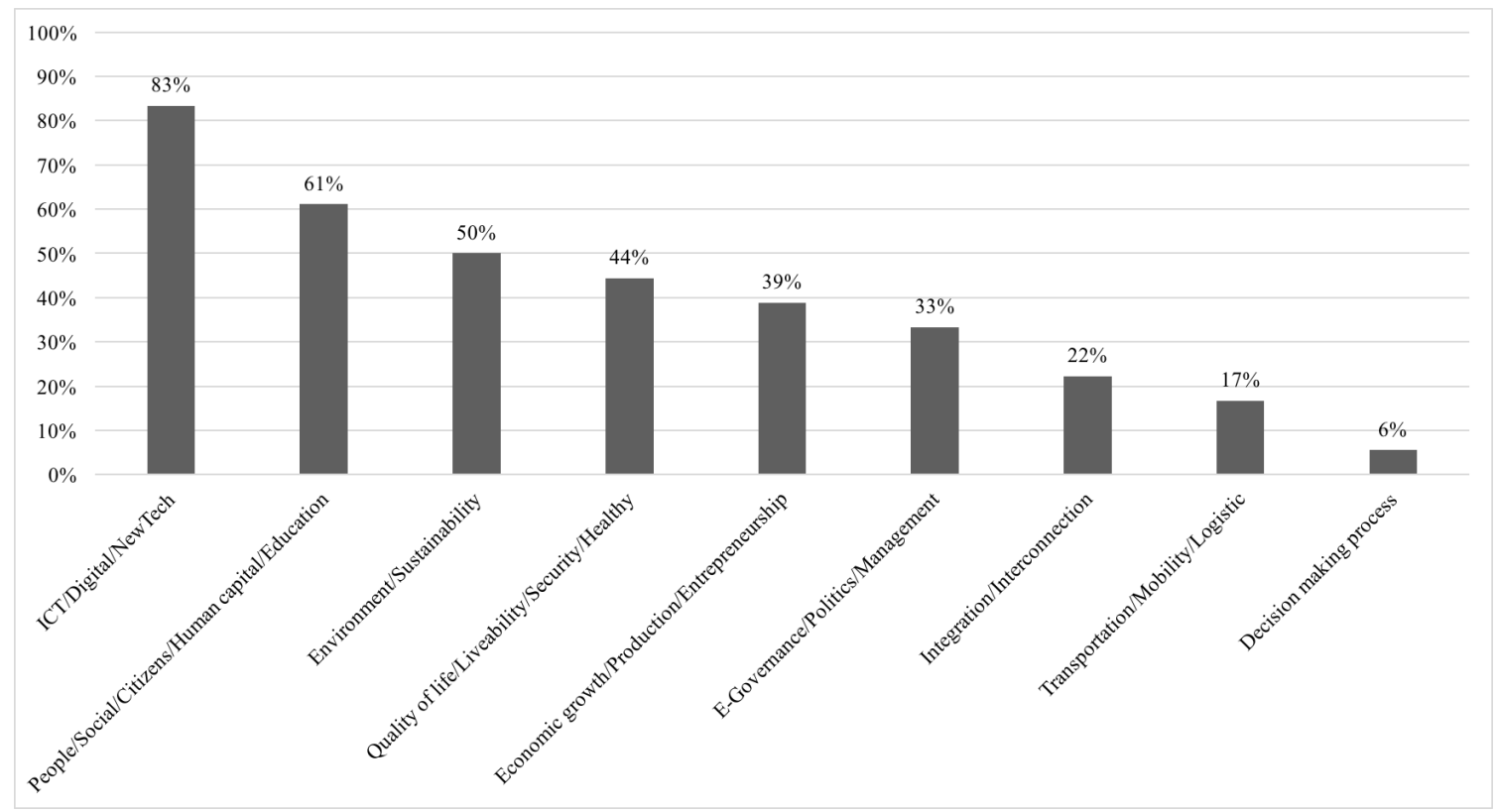

Figure 1. Smart City keywords in the European literature. 
Table 1. Smart City definitions

\begin{tabular}{|c|c|c|c|}
\hline Authors & Location & Definition & Focus \\
\hline [37] & Austria, Slovenia, The Netherlands & $\begin{array}{l}\text { A Smart City is a city well performing in a forward-looking way in these six characteristics (economy, mobility, environment, } \\
\text { people, living, governance), built on the "smart" combination of endowments and activities of self-decisive, independent and } \\
\text { aware citizens }\end{array}$ & $\begin{array}{l}\text { Technology, people, quality of life, economy, } \\
\text { mobility, e-governance, environment }\end{array}$ \\
\hline [5] & United Kingdom & $\begin{array}{l}\text { The utilization of networked infrastructure to improve economic and political efficiency and enable social, cultural, and urban } \\
\text { development, where the term infrastructure indicates business services, housing leisure and lifestyle services and ICTs }\end{array}$ & Technology, economy, people, e-governance \\
\hline [38] & Italy & $\begin{array}{l}\text { A city combining ICT and Web } 2.0 \text { technology with other organizational, design and planning efforts to dematerialize and speed } \\
\text { up bureaucratic process and help to identify new, innovative solutions to city management complexities in order to improve } \\
\text { sustainability and livability }\end{array}$ & Technology, quality of life \\
\hline [24] & Italy, The Netherlands & $\begin{array}{l}\text { A city is smart when investments in human and social capital and traditional (transport) and modern (ICT) communication } \\
\text { infrastructure, fuel sustainable economic growth and a high quality of life, with a wise management of natural resources, } \\
\text { through participatory governance }\end{array}$ & $\begin{array}{l}\text { People, mobility, technology, sustainability, } \\
\text { economy, quality of life, e-governance }\end{array}$ \\
\hline [39] & Italy, Egypt & $\begin{array}{l}\text { A smart city has smart inhabitants in terms of their educational grade. In addition, the term is referred to the relation between } \\
\text { the city government administration and its citizens. Good governance or smart governance is often referred to as the use of new } \\
\text { channels of communication for the citizens, e.g., "e-governance" or "e-democracy" }\end{array}$ & People, e-governance \\
\hline [14] & $\begin{array}{l}\text { Italy, United Kingdom, Ireland, } \\
\text { Israel, Canada, Switzerland }\end{array}$ & A city in which ICT is merged with traditional infrastructures, coordinated and integrated using new digital technologies & Technology \\
\hline [31] & The Netherlands & $\begin{array}{l}\text { They are the result of knowledge-intensive and creative strategies aiming at enhancing the socio-economic, ecological, logistic } \\
\text { and competitive performance of cities. Such smart cities are based on a promising mix of human capital (e.g. skilled labor } \\
\text { force), infrastructural capital (e.g., high-tech communication facilities), social capital (e.g. intense and open network linkages) and } \\
\text { entrepreneurial capital (e.g. creative and risk-taking business activities) }\end{array}$ & People, economy, environment, mobility, technology \\
\hline [21] & Italy, Romania & The smart city represents a community of average technology size, interconnected and sustainable, comfortable, attractive and secure & Technology, sustainability, quality of life, integration \\
\hline [26] & Spain & $\begin{array}{l}\text { Smart City implies a high-tech intensive and an advanced city that connects people, information and city elements using new } \\
\text { technologies in order to create a sustainable, greener city, competitive and innovative commerce and a recuperating life quality } \\
\text { with a straightforward administration and a good maintenance system }\end{array}$ & $\begin{array}{l}\text { Technology, people, sustainability, environment, } \\
\text { economy, e-governance, quality of life }\end{array}$ \\
\hline [35] & Greece & $\begin{array}{l}\text { The term "smart city" is understood as a certain intellectual ability that addresses several innovative socio-technical and } \\
\text { socio-economic aspects of growth. Cities prioritize their urban innovation ecosystems from their traditional urban character } \\
\text { to innovative "green", "smart", "open", "intelligent", and "innovating", aiming towards environmental and social sustainability }\end{array}$ & $\begin{array}{l}\text { People, technology, economy, environment, } \\
\text { sustainability, integration }\end{array}$ \\
\hline [20] & Italy & The concept of Smart City as a mean of enhancing the quality of life of citizens & Quality of life, people \\
\hline [40] & Italy & $\begin{array}{l}\text { Smart City proposes a holistic vision of future communities where new intelligent technological tools, services and applications } \\
\text { are integrated in a unique platform, providing interoperability and coordination between these several sectors. Furthermore, } \\
\text { Smart City also involves the definition of new governance instruments as well as new public and private funding methods }\end{array}$ & Technology, integration, e-governance \\
\hline [41] & United Kingdom & $\begin{array}{l}\text { The effective integration of physical, digital and human systems in the built environment to deliver a sustainable, prosperous and } \\
\text { inclusive future for its citizens }\end{array}$ & Technology, people, sustainability \\
\hline [36] & Portugal & $\begin{array}{l}\text { It becomes evident the importance of a quick and efficient action in order to identify, understand and work on the several } \\
\text { problematic issues concerning the quality of urban life. Thus being, and considering the emergence of the New Technologies of } \\
\text { Information and Communication - ICTs, as auxiliary tools for the monitoring, control and decision making towards these problems, } \\
\text { this subject has been evolving for consolidating urban management based in ICTs, namely the Smart Cities }\end{array}$ & Quality of life, technology, decision making \\
\hline [42] & Finland & There are two mainstreams in the smart city discussion: the ICT and technology-oriented approach and the people-oriented approach & Technology \\
\hline [43] & Norway & $\begin{array}{l}\text { Smart sustainable cities typically rely on the fulfillment of various ICT visions of pervasive computing, most notably the ICT where } \\
\text { everyday objects communicate with each other and collaborate across heterogeneous and distributed computing environments to } \\
\text { provide information and services to urban entities and urbanites }\end{array}$ & Sustainability, technology, people \\
\hline [44] & Italy & $\begin{array}{l}\text { An high-tech intensive and advanced city which connects people, information and various entities using new and advanced } \\
\text { technologies, with the aim to create a more sustainable and competitive model of city }\end{array}$ & Technology, people, sustainability \\
\hline [45] & USA & $\begin{array}{l}\text { The vision of "Smart Cities" is the urban center of the future, made safe, secure environmentally green, and efficient because } \\
\text { all structures-whether for power, water, transportation - are designed, constructed, and maintained making use of advanced, } \\
\text { integrated materials, sensors, electronics, and networks which are interfaced with computerized systems comprised of databases, } \\
\text { tracking, and decision-making algorithms }\end{array}$ & $\begin{array}{l}\text { Environment, mobility, integration, technology, } \\
\text { decision making }\end{array}$ \\
\hline
\end{tabular}


Table 1. Cont

\begin{tabular}{|c|c|c|c|}
\hline Authors & Location & Definition & Focus \\
\hline [32] & Canada & $\begin{array}{l}\text { A smart community will need to develop comprehensive plans to address, in more depth, the issues surrounding access and } \\
\text { education to ensure that all citizens and all organizations converge on the opportunities to benefit from the knowledge-based } \\
\text { economy. Smart communities will need to move beyond the focus on economic development and develop a coherent and compelling } \\
\text { vision that makes it clear how the new information networks are going to promote deeper engagement across local governance }\end{array}$ & Economy, people, technology, e-governance \\
\hline [33] & Canada & $\begin{array}{l}\text { Smart cities are city-regions that have been effective in using physical, informational and social technologies to generate effective } \\
\text { social learning through the good use of collective intelligence and all the relational synergies }\end{array}$ & Technology, people, integration \\
\hline [46] & USA & $\begin{array}{l}\text { A smarter city infuses information into its physical infrastructure to improve conveniences, facilitate mobility, add efficiencies, } \\
\text { conserve energy, improve the quality of air and water, identify problems and fix them quickly, recover rapidly from disasters, collect } \\
\text { data to make better decisions and deploy resources effectively, and share data to enable collaboration across entities and domains }\end{array}$ & Technology, mobility, economy \\
\hline [47] & Canada & Communities that are instrumented, integrated, and intelligent & Technology, integration \\
\hline [48] & USA & A city connecting the physical infrastructure to leverage the collective intelligence of the city & Technology, people \\
\hline [49] & USA & $\begin{array}{l}\text { The use of Smart Computing technologies to make the critical infrastructure components and services of a city which include } \\
\text { city administration, education, healthcare, public safety, real estate, transportation, and utilities more intelligent, interconnected, } \\
\text { and efficient }\end{array}$ & $\begin{array}{l}\text { Technology, e-governance, people, quality of life, } \\
\text { mobility, integration }\end{array}$ \\
\hline [34] & USA & $\begin{array}{l}\text { Makes optimal use of all the interconnected information available today to better understand and control its operations and } \\
\text { optimize the use of limited resources. [...]. They (cities) can improve their current service delivery capabilities (as well as lay the } \\
\text { foundation for new and expanded services) by making their core systems - transport, public safety, government services, education } \\
\text { and health-"smarter" }\end{array}$ & Integration, mobility, quality of life, e-governance, people \\
\hline [50] & Canada, USA & $\begin{array}{l}\text { We identify eight critical factors of smart city initiatives: management and organization, technology, governance, policy context, } \\
\text { people and communities, economy, built infrastructure, and natural environment }\end{array}$ & $\begin{array}{l}\text { Technology, e-governance, } \\
\text { economy, environment }\end{array}$ \\
\hline [51] & Canada & $\begin{array}{l}\text { La ville intelligente vise une intégration optimale des outils numériques pour garantir le bien-être des citoyens, un développement } \\
\text { économique et durable ainsi qu'une gouvernance intégrée }\end{array}$ & $\begin{array}{l}\text { Integration, technology, } \\
\text { economy, e-governance }\end{array}$ \\
\hline [52] & Canada & $\begin{array}{l}\text { A city that has deployed and integrated on a large scale advanced ICT, including wireless and broadband connections, advanced } \\
\text { analytics software and intelligent sensors to achieve significant improvements in efficiency and in the quality of life, and to help } \\
\text { change behavior among residents, businesses and government so cities can grow in a more sustainable way }\end{array}$ & $\begin{array}{l}\text { Integration, technology, people, economy, } \\
\text { e-governance, sustainability }\end{array}$ \\
\hline [53] & Canada & $\begin{array}{l}\text { Smart Cities (or Smart Communities more broadly) are connected places full of wireless devices and networks of sensors, cameras, } \\
\text { applications, and data centers supporting every aspect of community life. This technology supports the collection of real-time data, } \\
\text { measurement of performance through advanced analytics, and proactive responses to issues }\end{array}$ & Integration, technology, people, quality of life \\
\hline [54] & USA & $\begin{array}{l}\text { Smart City projects make cities work better. They apply information and communications technology to accurately monitor, } \\
\text { measure and control city processes, from transportation to water supplies, the location of city vehicles to the performance of electric } \\
\text { grids. Smart Cities are about saving money, becoming more efficient and delivering better service to the taxpayer }\end{array}$ & Technology \\
\hline [55] & USA & A smart city uses information and communications technology (ICT) to enhance its livability, workability and sustainability & Technology, quality of life, sustainability \\
\hline [56] & Canada & $\begin{array}{l}\text { Large, small, urban or rural communities fully employing e-health, e-work, e-commerce, e-education, and e-government for } \\
\text { providing the sustainable prosperity and full digital enablement }\end{array}$ & $\begin{array}{l}\text { Quality of life, economy, people, e-governance, } \\
\text { sustainability, technology }\end{array}$ \\
\hline [57] & Canada & $\begin{array}{l}\text { Smart Cities are places that recognize the trends and the need to embrace innovative alternatives. These are places that are working } \\
\text { to achieve new lifestyle benefits for residents, robust economic opportunities, and more efficient governance within a safe and } \\
\text { healthy environment. They often rely on networks of sensors, cameras, and wireless devices to do so-collecting real-time data, } \\
\text { measuring and optimizing performance, sharing results, and reporting issues even before they happen }\end{array}$ & $\begin{array}{l}\text { Quality of life, technology, people, } \\
\text { economy, e-governance }\end{array}$ \\
\hline [58] & Canada & $\begin{array}{l}\text { The Smart City is an integrated approach to improving efficiency, growing the local economy, achieving environmental sustainability } \\
\text { and improving the quality of life for citizens }\end{array}$ & $\begin{array}{l}\text { Integration, economy, environment, quality of } \\
\text { life, people }\end{array}$ \\
\hline [59] & Canada & $\begin{array}{l}\text { A Smart City creates sustainable economic development and high quality of life by considering innovation and technological } \\
\text { advancements as a key ingredient in its decision making, strategy and investment }\end{array}$ & $\begin{array}{l}\text { Sustainability, economy, quality of life, technology, } \\
\text { decision making }\end{array}$ \\
\hline
\end{tabular}




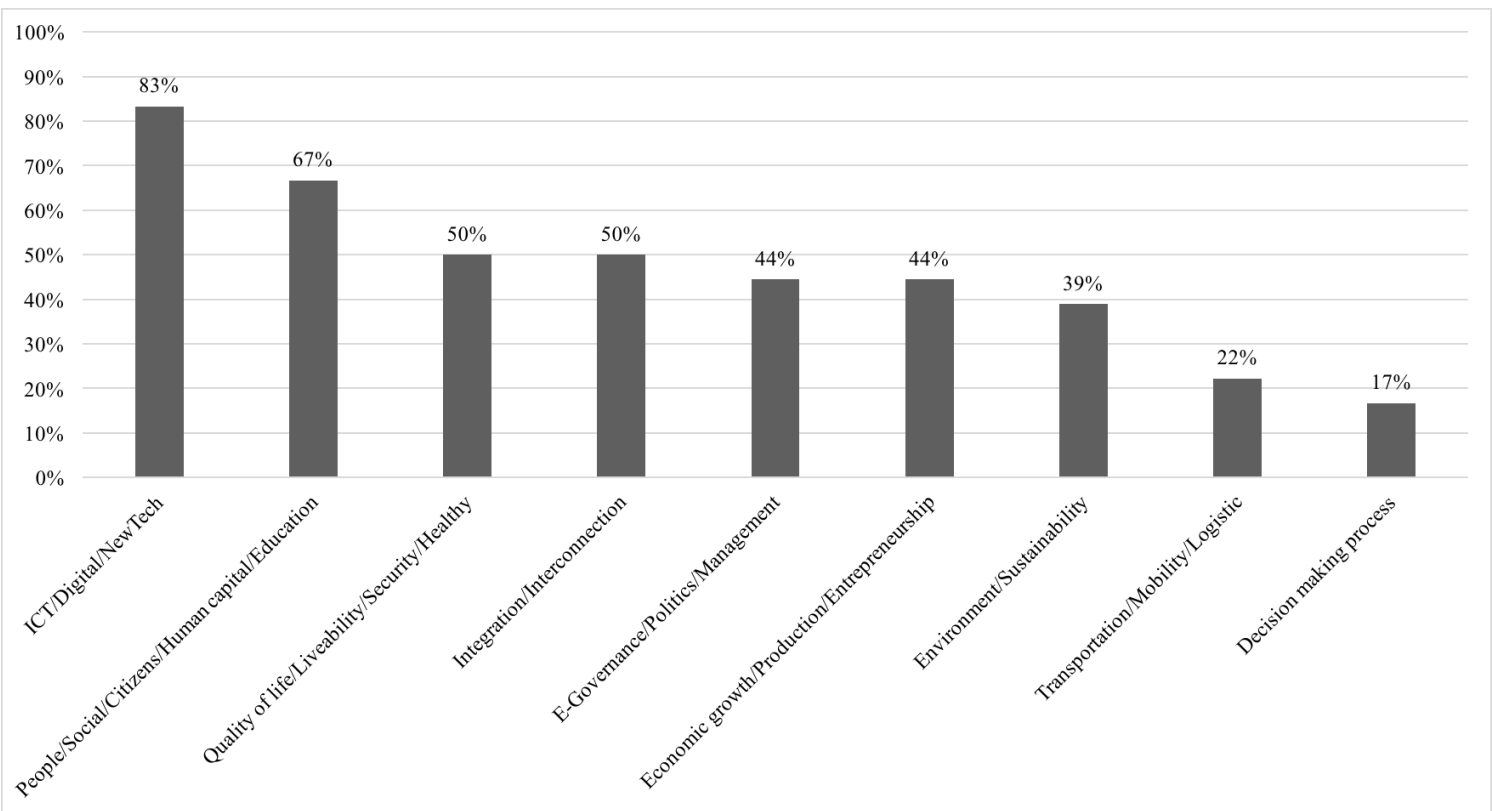

Figure 2. Smart City keywords in the North American literature.

\section{Methodology}

From a methodology point of view, our classification was a cluster-analysis-based taxonomy with polythetic classes [60,61]. Thus, to build it, we followed a three-step method [61]. First, we began with an empirical analysis of a database of SCPs. In the second stage, we represented the cluster on paper. Finally, the third stage was envisioning a mental concept for the cluster, often by mentally generating a name or label for the cluster (such as "Description").

We then started to gather information about projects from peer-reviewed journals, and conference proceedings as the source of smart city literature [29], project deliverables, local government reports. The following list of keywords was used to search for studies: smart city, smart city project, intelligent city. Then, we performed a screening according to the full availability of information and the stage of the project. It means that we considered SCPs ended, ongoing or at least already funded in 2017, under National, European and International calls, e.g., Horizon 2020 programme, Smart Cities and Communities and Social Innovation of the Italian Ministry of Education, University and Research, Smart City Communities Support Program by the Canadian Federal Government, Intelligent Community Forum and Smart City Council [54,62-64]. This filter yielded to a selection of about 105 outstanding SCPs (25 in Europe, 55 in Canada and 25 in the USA). Outstanding projects started with setting a high-level goal within a chosen area of focus, and achieved it through innovative solutions, obtaining results and gain of strategic relevance for both the city and community (e.g., a great reduction of environmental impact, inefficiencies or social exclusion). Their outcomes and innovations make these initiatives recognized at the national and international levels, becoming lighthouse projects. This large sample makes our analysis, even if not exhaustive, the most extensive screening of SCPs in the selected areas. Moreover, as we first investigated the scientific literature on smart cities and then the state-of-the-art in terms of SCPs from deliverables, reports and grey literature, our paper is positioned as a bridge between the two main development paths identified by the most recent bibliometric analysis on the field [65].

Our approach comprised a novel managerial analysis of the business models proposed by the SCPs following the GUEST methodology [66,67]. Thus, we produced a short document composed by of executive summary and a design of the Value Proposition and the Business Model related to the project $[68,69]$. We highlighted the needs, gains, and pains of the major stakeholders, as well as, the costs and revenues structures of SCPs. With this in mind, our paper aims to provide the government and project initiators a baseline to define more appropriate business models and policies 
for smart cities applications and financial self-sustainment in the long term, making these initiatives be a stronger bridge to the innovation and sustainable growth.

\subsection{Taxonomy}

In this subsection, we describe the architecture of our taxonomy with polythetic classes $[60,61]$ that extends and completes the original work [40]. Figure 3 depicts the result of the three-step method [61] used to build the taxonomy. The taxonomy is structured in three levels of detail. It provides three axes at the first level, which represent the main criteria used to classify the different aspects of the SCPs: Description, Business Model, and Purpose. Each axis is structured at the second level in several categories limiting the possible values while preserving the statistical significance. For each category at the second level, more precise information is provided by subcategories at the third level. Due to the large number of factors that play important roles in defining a smart city, we decided to consider only the axes at the root level as mutually exclusive and jointly exhaustive. For the sake of brevity, we describe in the following the first two levels of axes.

\begin{tabular}{|cccc|}
\hline \multicolumn{4}{c|}{ Description } \\
\hline Objectives & $\begin{array}{l}\text { Key Enabling } \\
\text { Technologies }\end{array}$ & Project initiator & Stakeholders \\
\hline Water & Cloud Computing & Private & City \\
E-Governance & Data Base & Public & Consumers / Citizens \\
Buildings & DSS & Mixed & Administration \\
CO Emissions & ICT & & SMEs \\
Energy & Innovative Sensors & & \\
Security & Legal and financial & & \\
& tools & \\
Social Innovation & Other new technologies & \\
Transportation & Portable Smart Devices & \\
& Smart Grids &
\end{tabular}

\begin{tabular}{ccc}
\hline \multicolumn{3}{c|}{ Business Model } \\
\hline Management & Infrastructure financing & Financial Resources \\
\hline Private & Private & Private \\
Public & Public & Public \\
Mixed & Mixed & Mixed
\end{tabular}

\begin{tabular}{ccc|}
\hline \multicolumn{3}{c|}{ Purpose } \\
\hline Client & Product & Geographical target \\
\hline Private & Specific & Urban \\
Public & No Specific & National \\
Mixed & & International
\end{tabular}

Figure 3. Dimensions and categories of our taxonomy.

\subsubsection{Description}

It provides an overview of the project and its context, with particular regard to its categories, to the objectives faced and the industry (Objectives), the tools and the technologies adopted (Key Enabling Technologies), the nature of the project initiator (Project initiator), and the key actors involved in an SCP (Stakeholders). In the following, we describe the categories contained in the Description axis:

- Objectives. As stated in the introduction, the term "Smart City" refers to several fields related to city management. We then grouped the project according to the most frequent objectives considered in a project.

- Key Enabling Technologies. As discussed above, the concept of "Smart City" is often related to the concept of ICT and these initiatives are intensively using technology [38,50]. All the Key Enabling Technologies are well-known technologies. Notice that we grouped in the items ICT and 
Other new technologies all the information technologies and the innovative ones (not included in the other items) useful to guarantee the value propositions of capturing and sharing data and information promptly.

- Project initiator. The initiator of an SCP, as in any other project, is the entity who begins the project. Both private and public sector are interested in promoting SCPs, with different purposes. The public sector aims to enhance the sustainability and liveability of cities while reducing the emissions and negative externalities. The private sector aims to improve efficiency, both in economic and operative standpoints, gaining competitive advantage. In several cases, public and private entities cooperate to find sustainable solutions to the growing issues.

- Stakeholder. A SCP is a multi-actor initiative, involving different parties (e.g., the city, customers, administrations, companies, universities and research institutions), each of them with own interests, objectives, and roles. Some of these actors (e.g., the universities) are already partnering with local councils and the private sector to collaborate on projects, engage in research and development and share data. At the same time, they have an active role in the smart cities' ecosystem through their use and improvement of smart technologies.

\subsubsection{Business Model}

The increasing Smart City interest leads to the need for redefining new business models and governance mechanisms. Thus, this axis addresses the aspects related to the project management and, the business and governance models. In particular, it investigates the nature of the project manager (Management) and the providers of infrastructures, equipment and financial resources (Infrastructure financing and Financial Resources). In the following, we describe the categories contained in the Business model axis:

- Management. The implementation of SCPs requires the collaboration within two or more entities. These collaboration can be public (i.e, the city or a public entity manages the SCP), private (i.e., a private company autonomously manages the project) or mixed. It is a hybrid approach, which has the form of Private Public Partnership (PPP). In fact, the city (Government) grants for a given number of years, the right to use public facilities to a private company. This grant is given according to fixed objectives and the perspective in reaching these objectives conditioning the renewal of the contract.

- Infrastructure financing and Financial Resources. An important building block of a Business Model is those concerning the key resources [68]. In SCPs they are mainly represented by physical assets as infrastructures, equipment, vehicles, and devices, or by financial resources essential for the project realization. Thus, the providers of these assets can be private, public or mixed.

\subsubsection{Purpose}

This axis classifies the SCPs according to their final goal. It identifies the user that will adopt and benefit of the solution developed by the project (Client), the type of product (Product) and the geographical target (Geographical target). In the following, we describe the categories contained in the Purpose model axis.

- Client. The outcome of the SCP can be addressed to different actors: private entities (i.e., citizens, small medium enterprises or private firms), public bodies or mixed.

- Product. Not all the SCPs have a specific goal, or better not all the projects during the beginning phases have already identified the final result that they want to reach. In the case of non-specific product, the product or service is still not defined, as technology could be not mature yet and the designers are still researching and develop. It could be even the case in which the project aims to put just the backbone for a smart-concept in order to stimulate and attract new investors with new projects and ideas. 
- Geographical target. The SCPs might regard a city area or a portion of that. Instead, there are some cases in which the project can be expanded at the national level. Especially in Europe, it used to adopt a pilot project. The idea is to test the conceptual project in one city to deeply understand the problem and its related issues. Once the implementation of the solution is done, the project can be scaled in other cities, gaining in term of time and cost. So, the project could even become transnational, thus involving different cities from different counties.

\section{Results}

This section presents a statistical analysis of the main projects in Europe and North America, showing how the concept of a smart city is declined in each region. It is based on data and information gathered through the application of our taxonomy to 105 outstanding projects in Europe (Section 4.1), Canada (Section 4.2), and the United States (Section 4.3).

\subsection{Europe}

In this section, we focus on the data we extracted from the panel of European projects.

Concerning the first axis of the taxonomy Description, Table 2 shows that the $92 \%$ of the SCPs face more than one objective. In particular, Energy and the reduction of $\mathrm{CO} 2$ Emissions are the most relevant objectives, followed by Buildings and Transportation (respectively, $56 \%$ and $52 \%$ ). Though the percentage of SCPs that address the $\mathrm{CO}_{2}$ Emissions is increased from the $11 \%$ to the $68 \%$ compared to the prior work [40] the trend remains the same. In particular, the combination of the objectives Energy, Transportation, Building and $\mathrm{CO}_{2}$ Emissions is confirmed as the most frequent in the multi-objective SCPs. In fact, the European SCPs ongoing or just ended focus on the reduction of $\mathrm{CO}_{2}$ and greenhouse gases emissions by refurbishment and energy retrofitting in existing residential buildings (e.g., City-zen project), through purchasing of electric and clean fuel fleet of cars, bikes and buses (e.g., Ele.c.tra project), and also using smart grid networks (e.g., Grid4eu project) to storage and resell extra energy produced and control energy consumption.

Table 2. Objectives of European SCPs. Notice that the sum of the percentage is more than $100 \%$ due to multi-objectives projects.

\begin{tabular}{lclr}
\hline Objectives & $\mathbf{\%}$ & Objectives & $\%$ \\
\hline \multicolumn{3}{c}{ Europe } \\
\hline Transportation & $52 \%$ & Water & $8 \%$ \\
Energy & $68 \%$ & Security & $12 \%$ \\
Buildings & $56 \%$ & E-Governance & $24 \%$ \\
$\mathrm{CO}_{2}$ Emissions & $68 \%$ & Social Innovation & $32 \%$ \\
\hline Multi-Objectives & $92 \%$ & & \\
\hline
\end{tabular}

New Technologies (e.g., RFID and GIS technologies, innovative daylight collectors) are the most used tools $(88 \%)$, followed by ICT-based Decision Support systems (72\%), and Smart Grids and Innovative Sensors (36\%) (see Figure 4). This result highlights the higher propensity of European countries to adopt innovative technologies rather than the USA, where Cloud Computing is the most used tool in the SCPs, or than Asia, where ICT tools, Database, and Innovative Sensors are the most present. This finding reflects the increasing diffusion of the IoT for Smart Mobility and City Logistics issues [70]. 


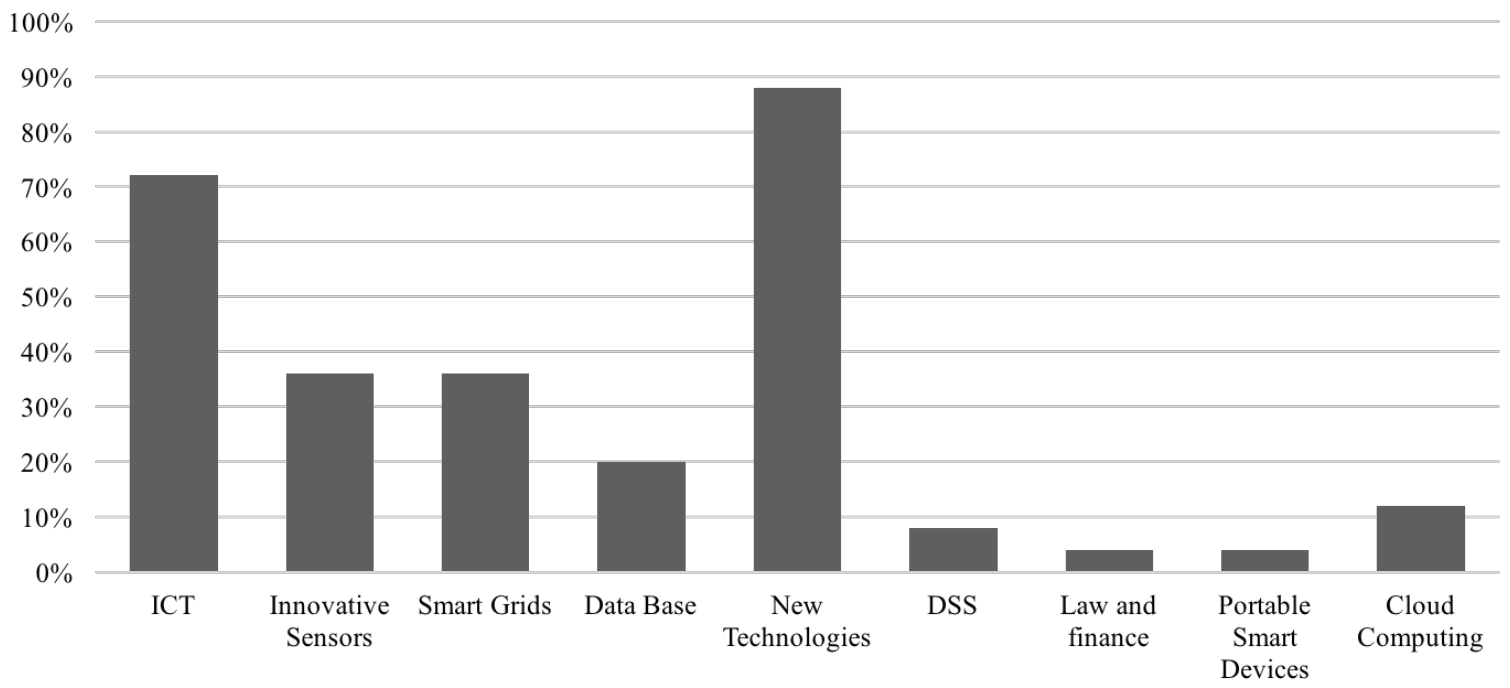

Figure 4. Key Enabling Technologies adopted in European SCPs.

Analyzing the role of the public sector emerges how the public support is fundamental to launch and sustain the smart city initiatives. In fact, the percentage of SCPs in which public entities participate as Project Initiator rises from the $56 \%$ of the previous to the overall sample considered in our study. A reason for this trend is the high number of European-funded projects arisen from the call of the Horizon 2020 Programme. The relevance of the public sector is also confirmed by the outcomes we obtain from the Business model axis and the Client category of the Purpose axis. In fact, Figure 5 shows how government programs mainly manage the projects, supported by partnerships with private companies. As it happens for the SCPs initiatives in other continents like Asia, also in Europe the participation of the public entities is strategic as providers of financial resources, infrastructures, and equipment.

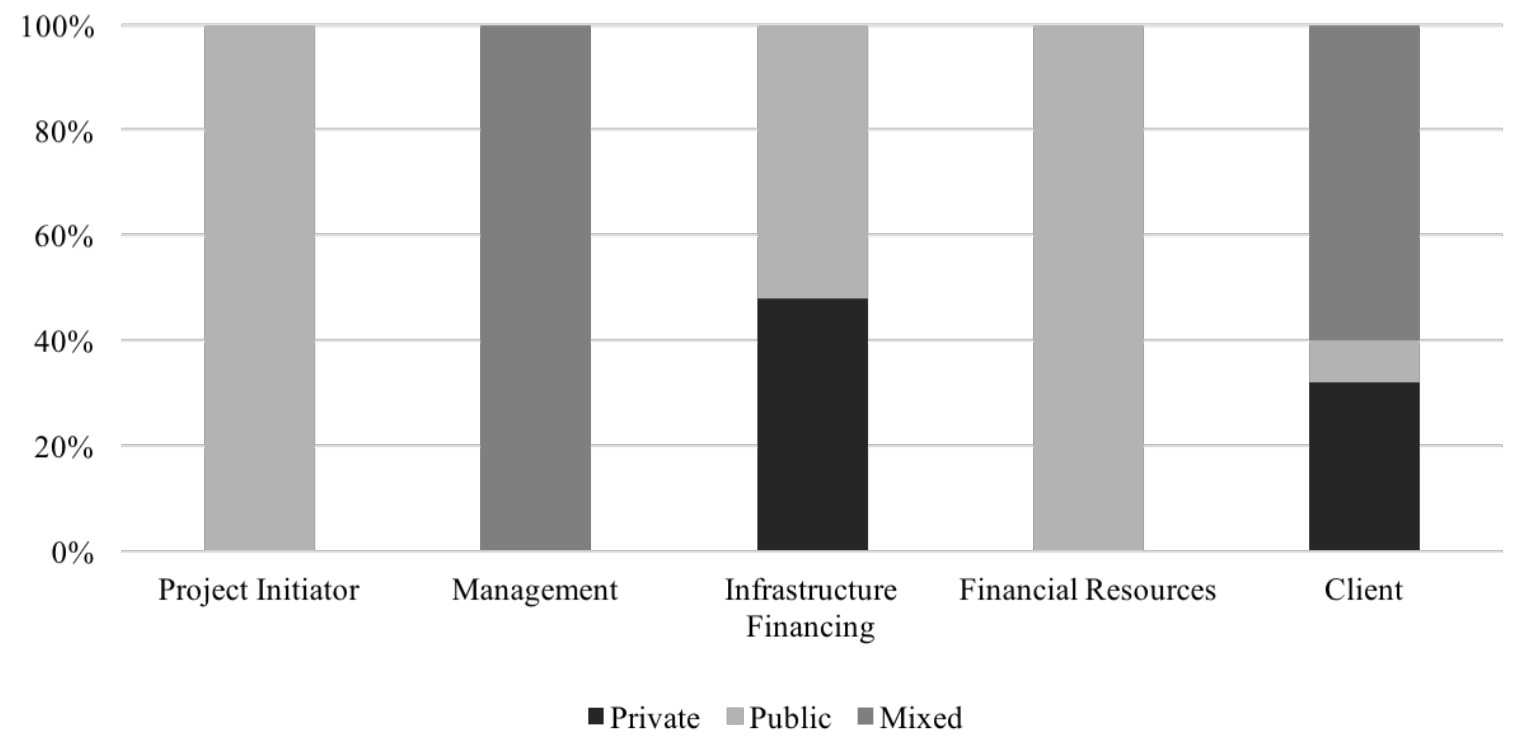

Figure 5. Role of private, public and mixed entities in the management, financing and usage of solutions in European SCPs.

In particular, in the $52 \%$ of the total projects, the infrastructure financing comes from the public sector, eventually under PPPs form of cooperation (32\%), while, in the remaining $48 \%$ the infrastructures are only private. Moreover, in all the SCPs, some financial support is provided by the 
public sector, even if only the $16 \%$ is public, while the significant part of projects uses mixed resources. Finally, in the $68 \%$ of the projects, they are directed to public or mixed customers.

Regarding the Stakeholders (Figure 6), the strong involvement of universities and enterprises results in the European initiatives. In particular, the $84 \%$ of projects involve the universities and research institutions as providers of high-level knowledge and technology transfer. Moreover, all the SCPs has one or more industrial partners, also to promote the education-industry partnerships at European-level.

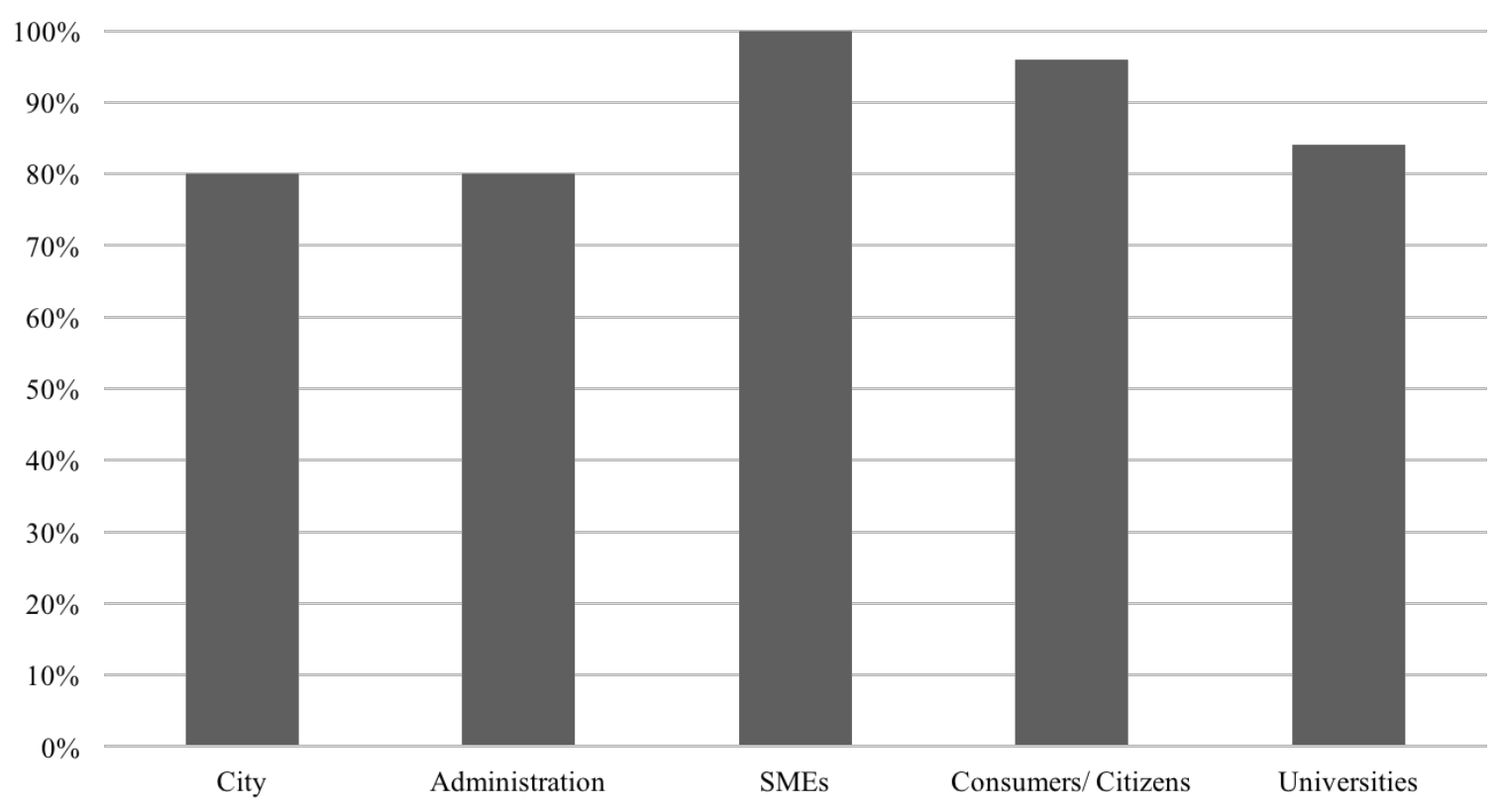

Figure 6. Stakeholders involved in European SCPs.

The $100 \%$ of the SCPs are pilot or experimental projects focused on the specific characteristics of the products and solutions. Finally, the geographical target of European SCPs (see Figure 7) is mainly national and international (96\%), involving several cities, with the aim of sharing solutions [40].

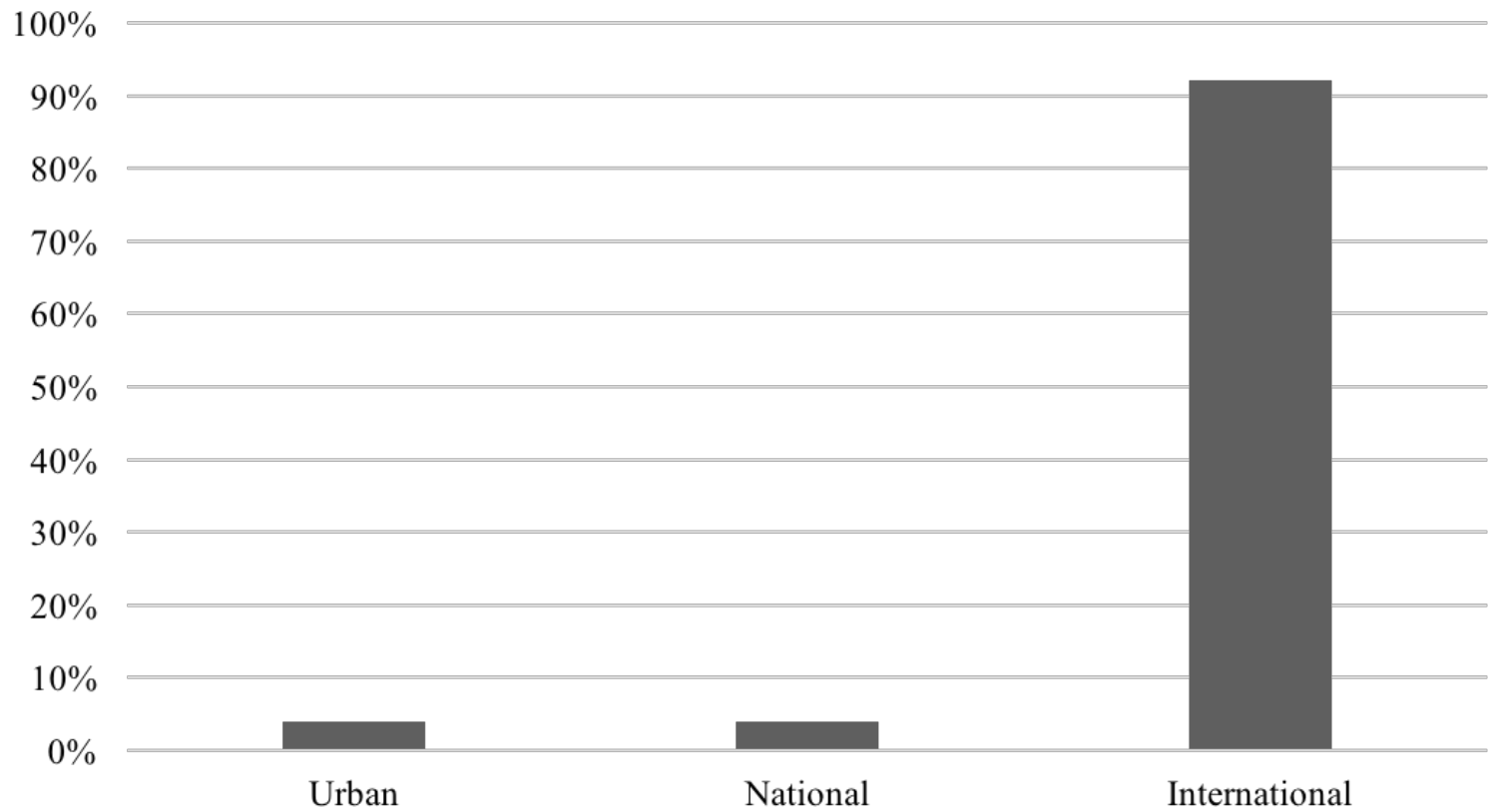

Figure 7. Geographical target of European SCPs. 


\subsection{Canada}

In this section, we analyze the results of the taxonomy applied to the sample of SCPs in Canada.

As evidenced in Table 3, the predominant objectives are first Energy ( $42 \%$ of SCPs), followed equally by Transportation and Social Innovation representing 38\% each, and then $\mathrm{CO} 2$ emissions and Security with $33 \%$. This trend is confirmed in almost all the regions of Canada, while Ontario is an exception showing a higher interest for Energy accompanied by CO2 Emissions (respectively 43\%) than associated to Transportation (14\%). On the other hand, the Prairies and British Columbia are developing projects, not surprisingly, related to Water management $(44 \%)$, expected because these two regions stand out for their natural resources, and security.

Projects having multiple objectives are $64 \%$ of the total, most of them related to Energy. The most frequent partners of Energy are the objectives of the reduction of $\mathrm{CO}_{2}$ Emissions and Water. Therefore, it is possible to conclude that Canada is showing an interest in the green energies.

Table 3. Objectives of Canadian SCPs. Notice that the sum of the percentage is more than $100 \%$ due to multi-objectives projects.

\begin{tabular}{lclc}
\hline Objectives & $\%$ & Objectives & $\%$ \\
\hline \multicolumn{3}{c}{ Canada } \\
\hline Transportation & $38 \%$ & Water & $22 \%$ \\
Energy & $42 \%$ & Security & $33 \%$ \\
Buildings & $20 \%$ & E-Governance & $27 \%$ \\
$\mathrm{CO}_{2}$ Emissions & $33 \%$ & Social Innovation & $38 \%$ \\
\hline Multi-Objectives & $64 \%$ & & \\
\hline
\end{tabular}

The Key Enabling Technologies attribute is described in Figure 8. ICT is the most popular tool $(62 \%)$ used in Canadian SCPs, followed by New Technologies (58\%). An example of the use of ICT tools, not only composed by Wireless Internet but also other communication devices, is the contract issued by the City of Montréal for the implementation of a smart public lighting management system, consisting in an infrastructure capable of controlling 135,000 luminaries. Although Energy is the predominant objective of the SCPs, the less used tools are the Smart grids (13\%). This result is justified by the interest of Canada towards the development of renewable energies using new technologies as the hydroelectric plants in Manitoba and Québec, the wind turbines and solar photovoltaic projects in Ontario, the water treatment plants in British Columbia, the Solar Resource Map in Québec, and the Waste Management Facilities in Edmonton, Alberta.

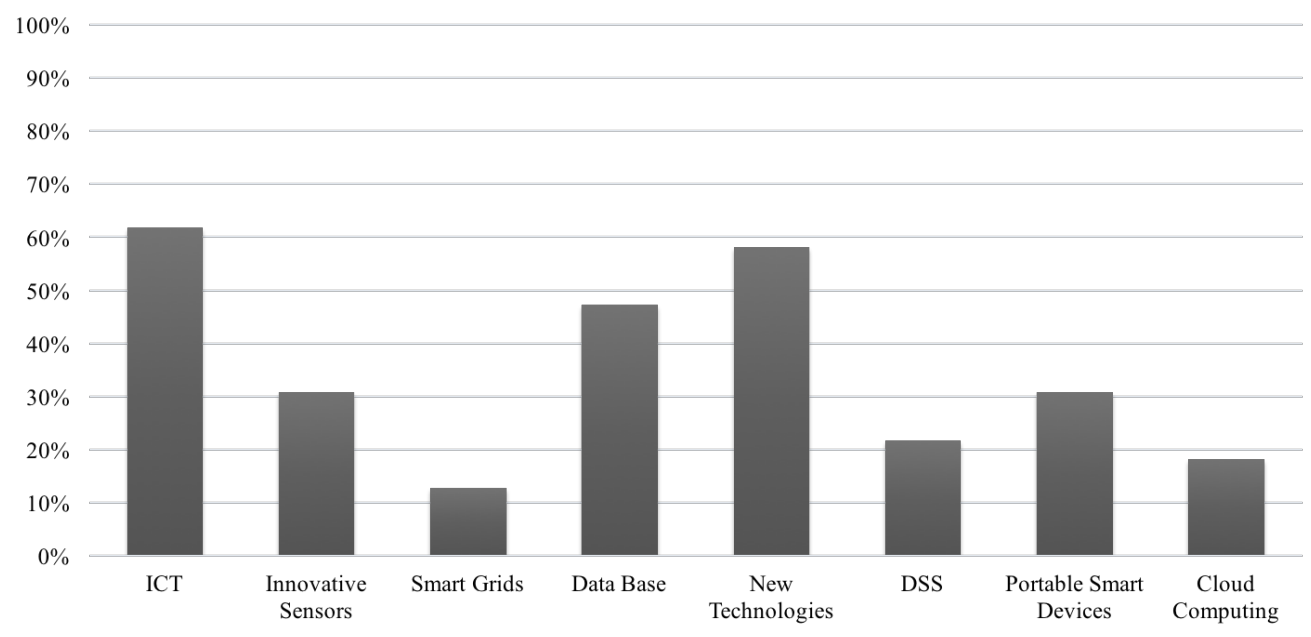

Figure 8. Key Enabling Technologies adopted in Canadian SCPs. 
As in Europe, also in Canada, most of the SCPs are driven by government and public entities. Indeed, the public sector is the initiator in $89 \%$ of the projects. Mixed and private initiators are minimally detected with $7 \%$ and $4 \%$ respectively (see Figure 9 ).

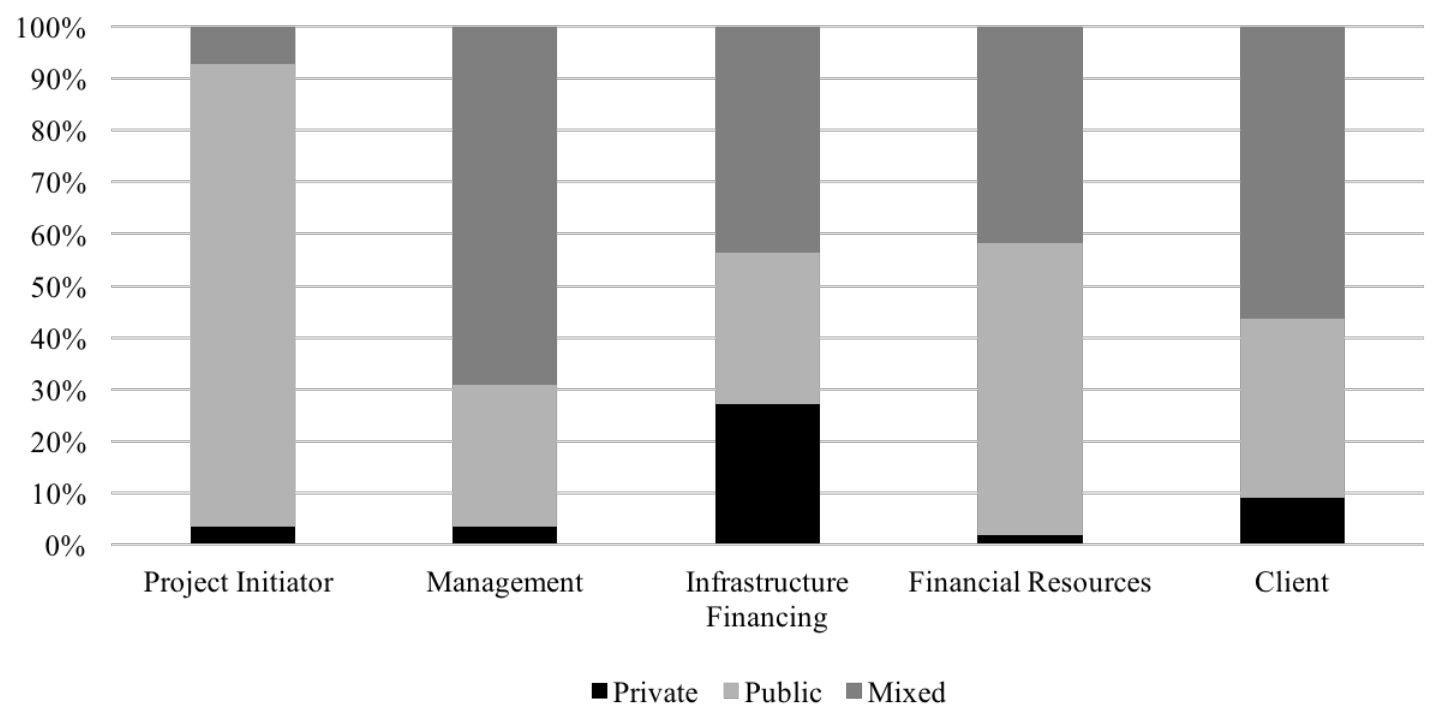

Figure 9. Role of private, public and mixed entities in the management, financing and usage of solutions in Canadian SCPs.

Considering the business model axis, the mixed sector assumes a more central role, especially in the management of the projects (69\%). For the implementation of SCPs, it is rare to encounter a project that does not involve the collaboration of two or more entities from different sectors. In the financing of the infrastructure, the funding distribution seems to be equitable between public (29\%) and private sectors $(27 \%)$. In contrast, the financial resources, like in the project initiator case, come mostly from the public sector, as only public financial resources (56\%) or mixed with a private contribution $(42 \%)$. Projects are seldom financed just by the private sector $(2 \%)$.

Moreover, the public sector has a relevant role as a client of the SCPs solutions in fact, in over the half of the cases (56\%), the final client is mixed, while the $35 \%$ of cases have just a public client, and in the $9 \%$ of the projects the customer belongs to the private sector.

The stakeholders perspective is illustrated in Figure 10. The stakeholders with the greatest participation are the City (91\%) and the Customers/Citizens (85\%). On the contrary, Universities are the less involved actors in the SCPs $(29 \%)$.

Concerning the geographical target of SCPs, on the contrary to the European trend, more than half of the initiatives in Canada concern a unique city or town (Figure 11). The SCPs focused on a national level (and thus involving more cities within Canada) are close to $35 \%$, while less than $10 \%$ of the projects pretend to be extended at international levels. This trend is supported by the characterization of the political system, in which the authorities in charge of developing SCPs are at the provincial and municipal level and thus, focused on the local welfare rather than an international enlargement. 


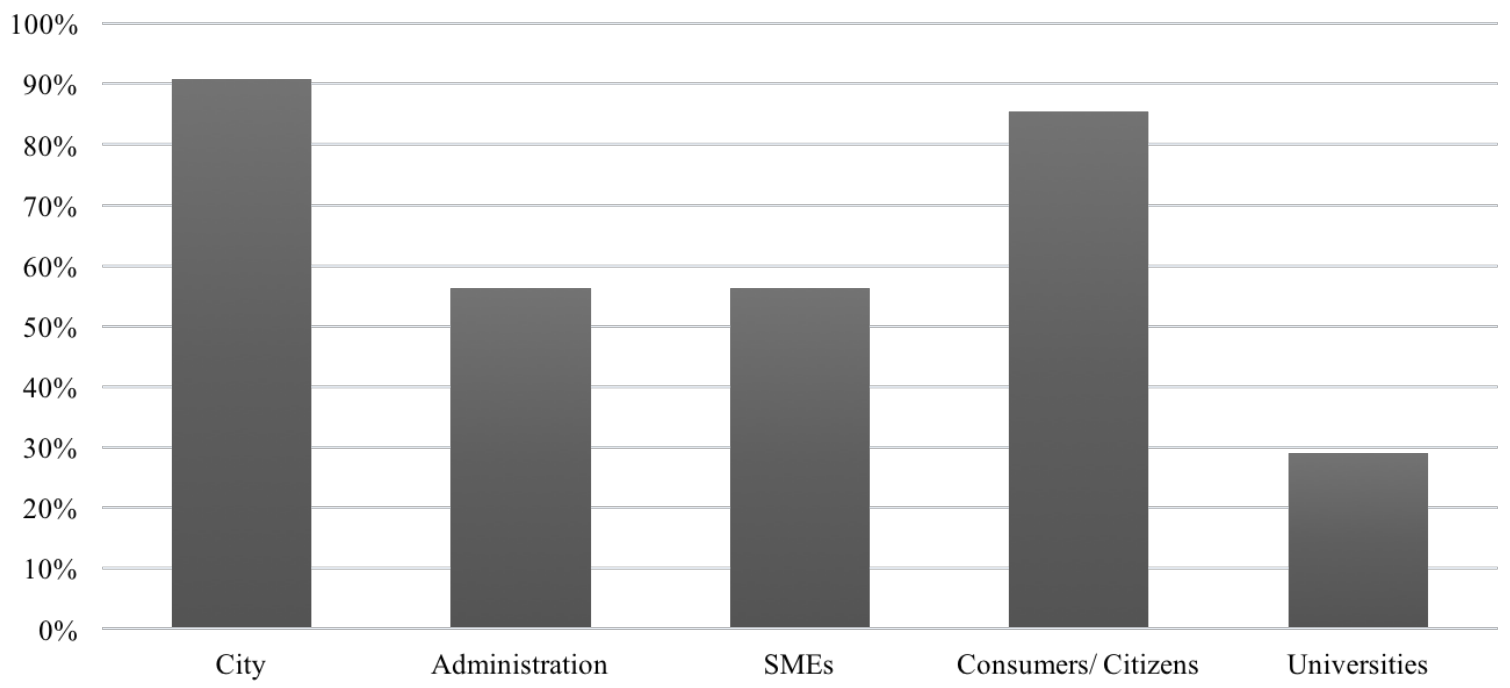

Figure 10. Stakeholders involved in Canadian SCPs.

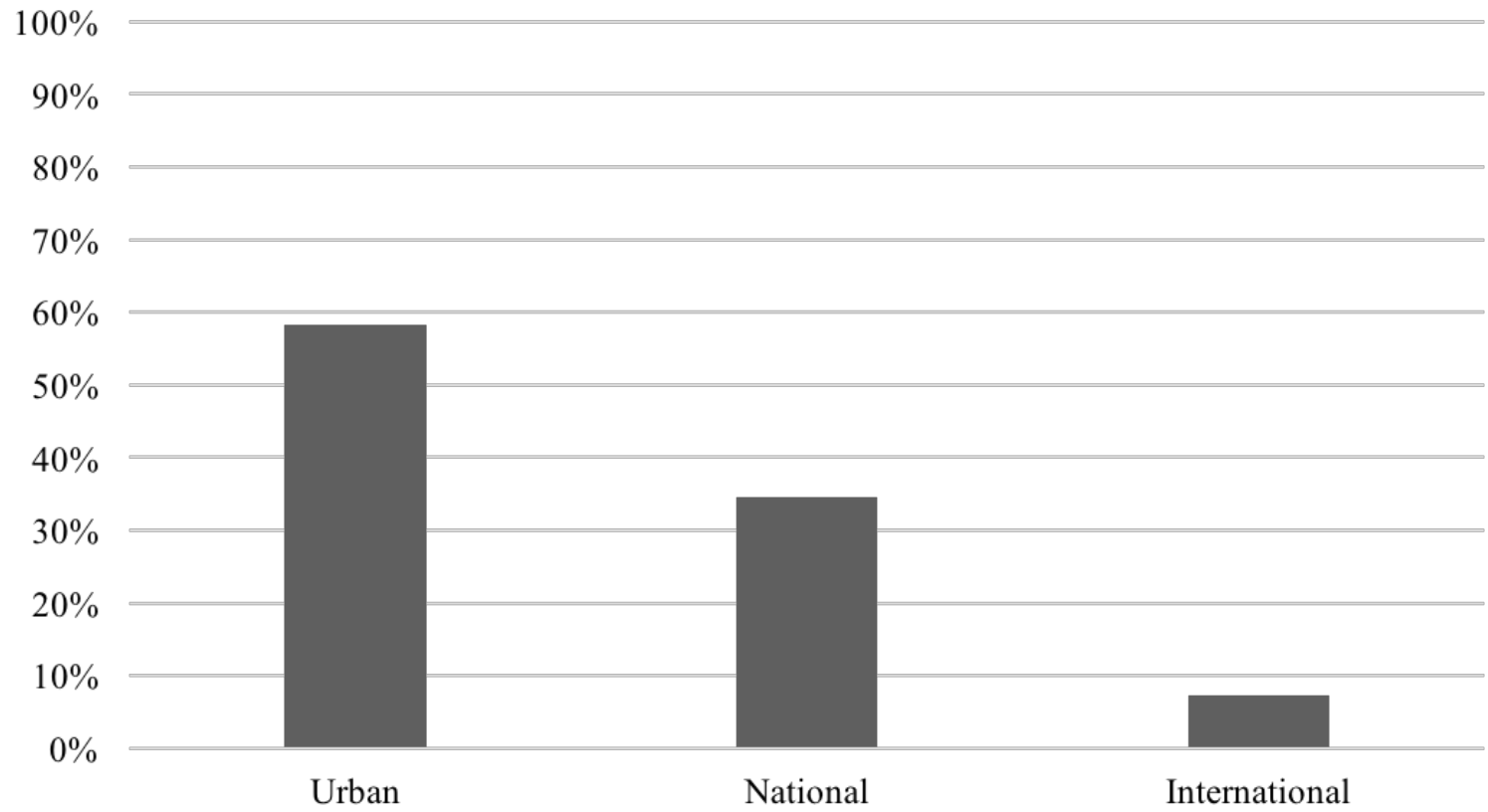

Figure 11. Geographical target of Canadian SCPs.

\subsection{The United States}

To conclude our analysis of SCPs in North America, we discuss in this section the results of the application of the taxonomy to the initiatives in the USA.

As done for the previous sections, we start the discussion with the Description axis. Concerning the objectives, as shown in Table 4, the significant part of SCPs in the USA is focused on Transportation (60\%), followed by $\mathrm{CO}_{2}$ Emission (52\%) and Energy (44\%). More in detail, the 68\% of projects are multi-objective including Transportation, and the $36 \%$ of them involve all the three objectives mentioned above in the same project. An example is the Beyond Traffic initiative of Kansas City to meet the Smart City Challenge in 2016. On the contrary, Water, E-Governance and Building are the less explored sectors in smart city topic (about $24 \%$ of projects). 
Table 4. Objectives of US SCPs. Notice that the sum of the percentage is more than $100 \%$ due to multi-objectives projects.

\begin{tabular}{llll}
\hline Objectives & \% & Objectives & $\%$ \\
\hline \multicolumn{3}{c}{ USA } \\
\hline Transportation & $60 \%$ & Water & $24 \%$ \\
Energy & $44 \%$ & Security & $36 \%$ \\
Buildings & $20 \%$ & E-Governance & $24 \%$ \\
$\mathrm{CO}_{2}$ Emissions & $52 \%$ & Social Innovation & $36 \%$ \\
\hline Multi-Objectives & $68 \%$ & \\
\hline
\end{tabular}

Figure 12 depicts the distribution of the tools used in SCPs in the USA. Similarly to Canada, the most used tools are ICT, Data Base and Cloud Computing, respectively the $80 \%, 80 \%$ and $60 \%$ of SCPs.

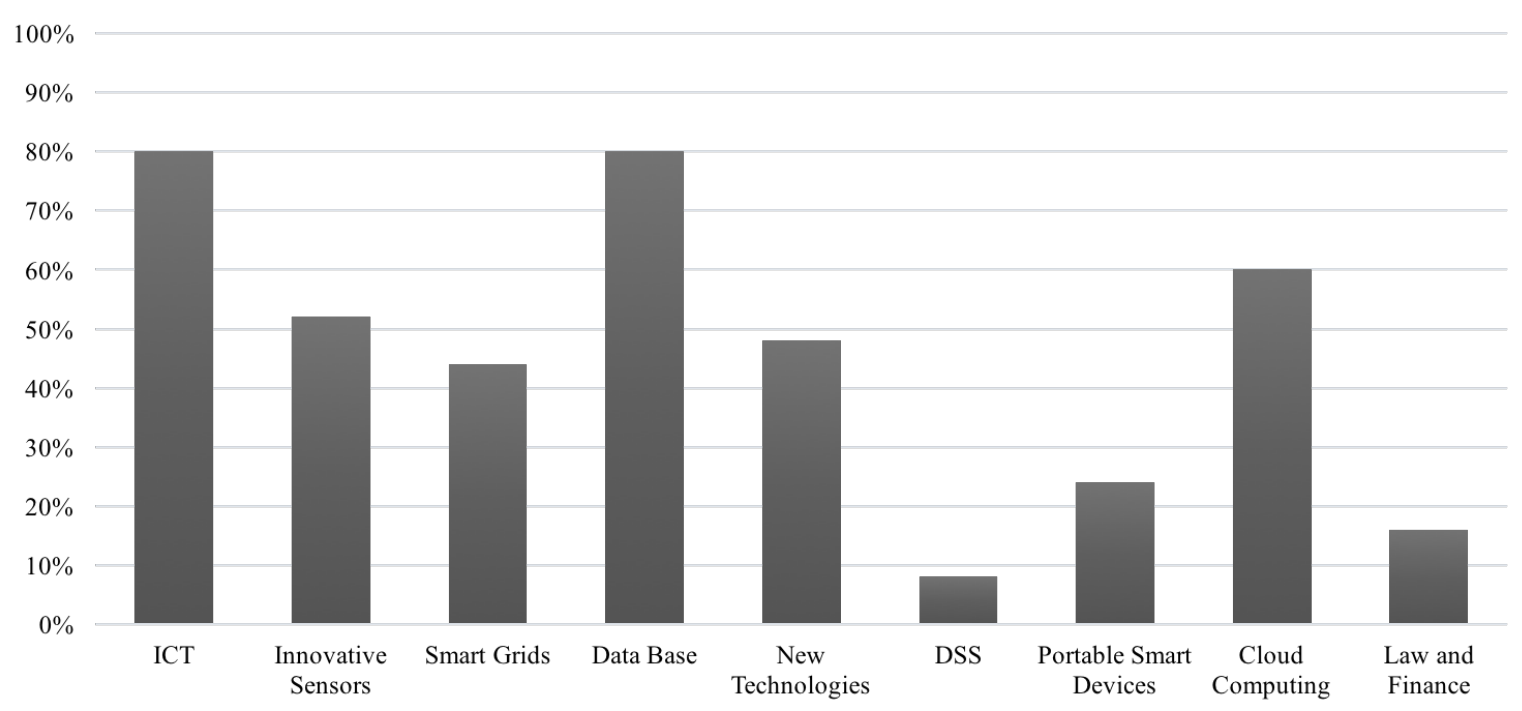

Figure 12. Key Enabling Technologies adopted in US SCPs.

Figure 13 shows that, as in Canadian SCPs, the public sector has a relevant role in initiatives, both alone (44\% of SCPs) or within private-public partnerships ( $24 \%$ of SCPs). The private sector promotes the remaining $32 \%$ of initiatives.

Concerning the infrastructure financing and the financial resources, the results highlight that mixed partnerships support about $40 \%$ of the SCPs, while the projects funded by only private or public sectors are more or less equally distributed. As emerged in Europe and Canada, in a significant number of the initiatives, the client is mixed (48\%). However, the same percentage of projects in the United States has a private client, thus mostly oriented toward companies.

Figure 14 shows that the stakeholders with the greatest participation in US projects are the Customers/Citizens (100\%), SMEs (88\%), and City (72\%). On the contrary, Universities are the less involved actors in the SCPs $(40 \%)$. 


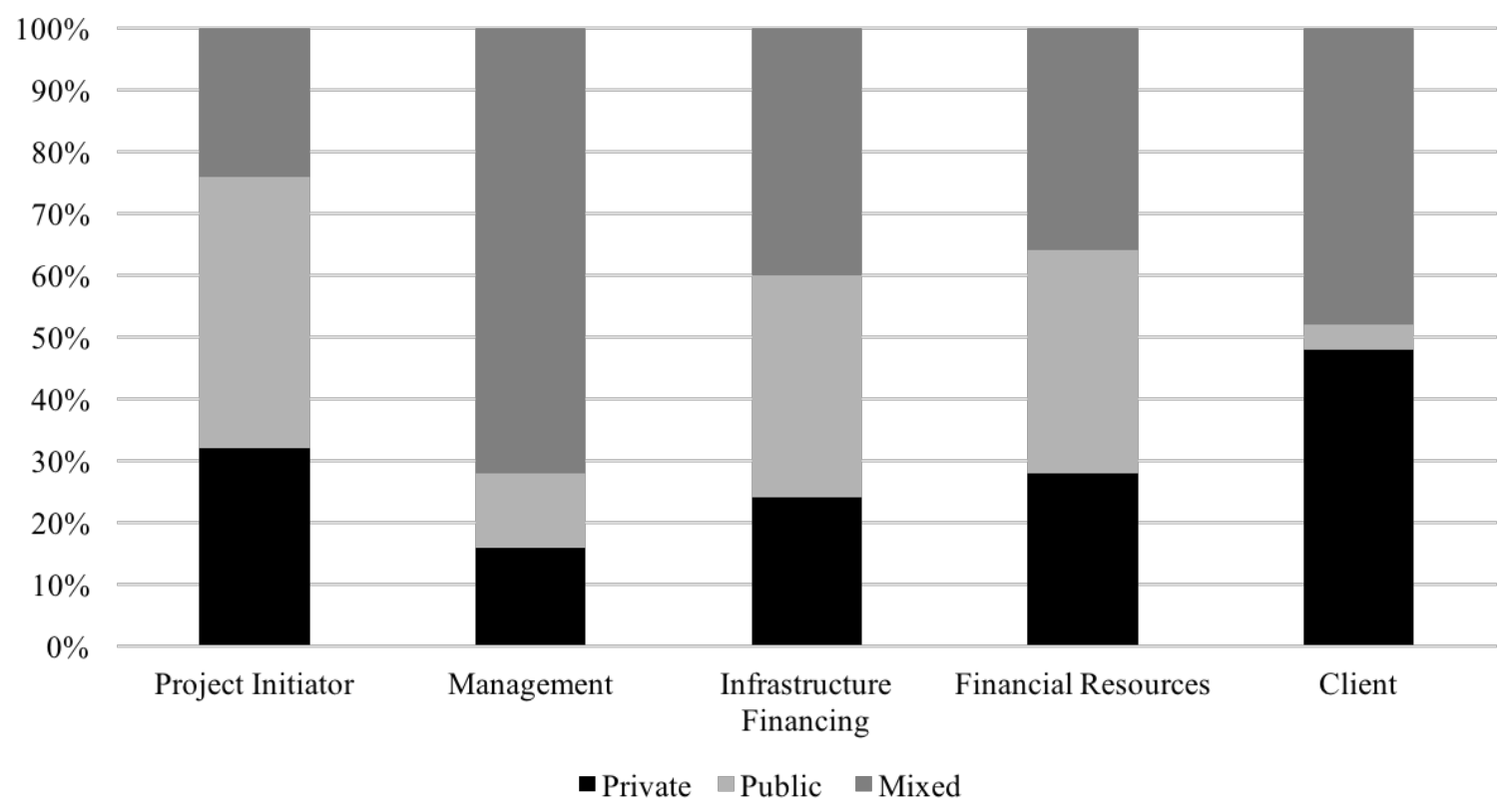

Figure 13. Role of private, public and mixed entities in the management, financing and usage of solutions in US SCPs.

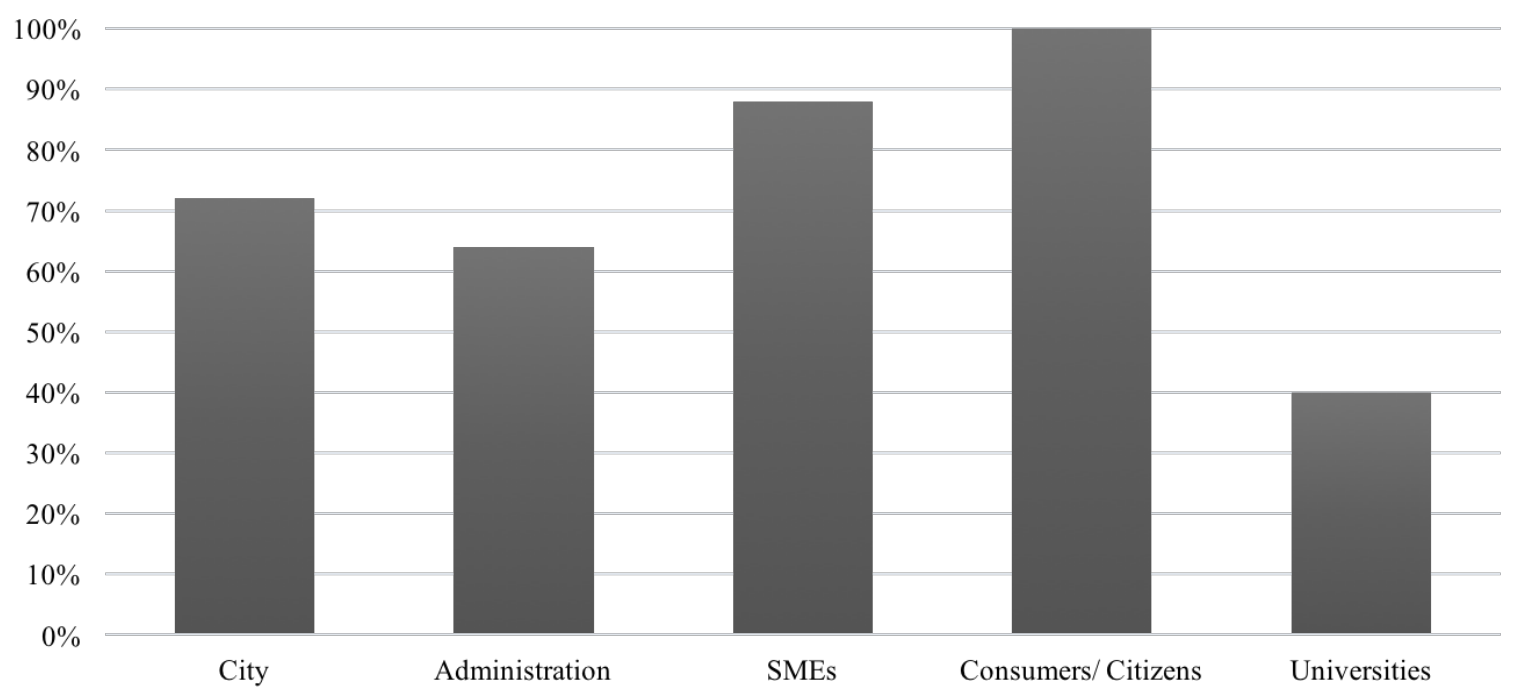

Figure 14. Stakeholders involved in US SCPs.

Analyzing the output of the last two categories of the Purpose axis, it emerges that the $68 \%$ of the SCPs are focused on the specific characteristics of the products and solutions. Finally, Figure 15 shows the geographical target of the US SCPs. Initiatives in the United States are mainly urban (84\%). Few projects $(16 \%)$ embrace national and international levels. 


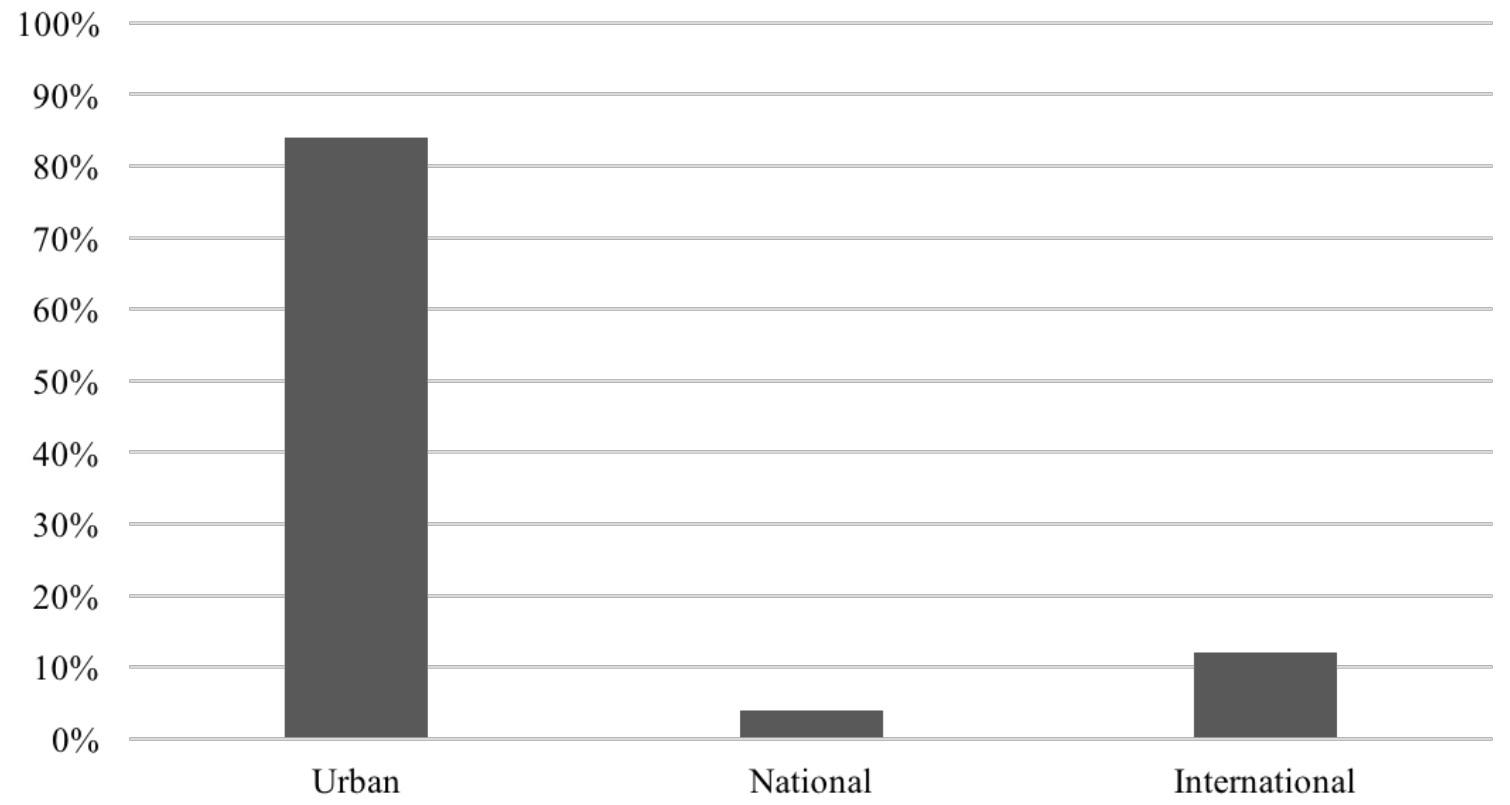

Figure 15. Geographical target of US SCPs.

\section{Conclusions}

This paper investigates the current state-of-the-art of SCPs in Europe and North America to obtain a broad view and highlight trends and future paths. The results obtained from the application of the taxonomy to the sample of projects highlight that a significant part of current initiatives addresses different objectives in the same project, reflecting the interest of the local government to such aspects of the city management. In particular, although Energy is a common objective, in Europe it is mainly associated with the reduction of $\mathrm{CO}_{2}$ Emissions, while in North America it is associated with Transportation. The pressure of the European Commission that through several calls aims to achieve environmental integrity, resilience and sustainability of activities justifies this result. On the other hand, the logistics and transportation industry in North America is highly competitive and plays a relevant role in the government's agendas. According to this result, it is not surprising that after ICT and New Technologies, the most used tools in SCPs are Smart Grids and Sensors in Europe, and Database and Cloud Computing in North America where, particularly in the USA, government organizations have aggressively begun to capitalize on them.

Concerning the role of public sector, results show its greater involvement in Europe than in North America, and also in Canada than the USA, where the private sector assumes a valuable function as project initiator, provider of financial resources, and client. Notice in particular as in Europe SCPs mainly arise in reply to government calls or public-interest challenges, while in Canada projects are mainly fostered by PPPs. On the contrary, in the USA there is a significant percentage of projects initiated by private companies. Infrastructure financing is an exception. In fact, while in America private sector is investing in infrastructure projects that can provide stable, long-term returns, through PPPs or other innovative investments, in Europe there is a clear dividing line between public and private infrastructure financing.

Regarding the stakeholders, the findings resulted by the taxonomy confirm the social-orientation of SCPs, which are mainly devoted to guarantee better living conditions in cities and improve the quality of life of citizens. However, a substantial result is the lower involvement of universities in North America than in Europe. This trend represents a key challenge for Canadian cities and universities to raise the collaboration. An attempt is the first university-based smart grid laboratory, named Schneider Electric Smart Grid Laboratory. It is created by the Centre for Urban Energy at Ryerson University in partnership with Schneider Electric and sponsored by Ontario Ministry of Energy. Cities and 
companies can take advantage of academic formation of students to create research projects of interest for all the stakeholders. Even if it is commonly recognized the orientation of Europe to social protection and welfare policies, political transformations led to a rapid change in cities to an entrepreneurial urban form.

The last main difference between European and North American SCPs concerns their geographical target. While European projects are mainly at national or international level embracing more cities, the Canadian and US initiatives are focused on a single city and thus, at the urban scale. Indeed, European Commission with the several calls is explicitly fostering the creation of European SCPs that embrace more than one country with most of the times few lighthouse cities at the early stage of the project and then, other cities followers, with the aim of sharing solutions. More in general, prior work has highlighted a maturity of the SCPs from a technological standpoint. In fact, initiatives are mainly focused on improving the cities conditions, proposing advanced solutions with a high technological content. However, although recent projects start to promote new collaborative business models, more integration of the business and governance models is still lacking, compromising the feasibility, the profitability and thus, the sustainability of the project.

In conducting our study, we experienced two main limitations. First, there is poor availability of information and data on SCPs. On the one hand, although in websites as those of the European Commission and the Smart Cities Council, several deliverables and information about projects are available, there are no formally recognized entities storing and organizing information. On the other hand, while the projects proposals are clearly defined, their economic and financial aspects as well as their results and lessons learned, are less present. In fact, the outcomes of our analysis highlight the need of merging the efforts at the international level, in gathering information and data on SCPs in a more structured manner. Second, another limitation concerns the processing and handling of large datasets manually. Thus, with a view to enhance the methodology and apply the taxonomy on larger databases of SCPs in different regions, the findings of this work could be used to build intelligent systems that are well suited with the need to gather data in a structured and comprehensive way.

Concerning future directions, we see mainly two axes: one methodological and one related to the business modeling.From a methodological point of view, as mentioned before the main problem encountered in our analysis of the SCPs was the fragmented process for retrieving information and data. This aspect makes difficult the monitoring of the smart cities' conditions. Thus, a more structured view of the topic is necessary, by introducing standard taxonomies of the projects and common data sources where that information is stored. This is crucial not only for the descriptive part of the projects, as shown in this paper, but also for evaluation of them, and in particular of the projects that have no commercial or public follow-up. The adoption of a methodology able to collect and structure people-oriented failure causes was already proved to be effective in similar cases, as the detection of death paths for Startups [71]. We then see a possible research direction in extending methods as the SHELL Startup to Smart Cities Projects. Concerning the business modeling, one of the main lacks in all the projects is the business perspective itself. In fact, the majority of the projects build their value with a high technology perspective, disregarding the business development phase and giving insufficient exploitation support. This issue has some outcomes. The product/service rarely survive to the end of the pilots. Moreover, the product/service is not tested in a real market environment, or a clear customer discovery phase is performed [72]. So, in all the projects more attention should be paid to the adoption of Innovation and Business Development methodologies and to require, as project outputs, a clear exploitation plan. We then see a clear research direction in creating a standard framework for the exploitation of the projects.

Author Contributions: Data curation, G.P. and M.R.; investigation, G.P. and M.R.; methodology, G.P. and M.R.;writing-original draft preparation, G.P. and M.R.; writing-review and editing, G.P. and M.R. The authors contributed equally to this work. All authors have read and agreed to the published version of the manuscript.

Funding: This research received no external funding. 
Acknowledgments: While working on this paper, the first author was the Director of the ICT for City Logistics and Enterprises Lab and the head of the Urban Mobility and Logistics Systems (UMLS) initiative of the interdepartmental Center for Automotive Research and Sustainable mobility (CARS) at Politecnico di Torino, Italy.

Conflicts of Interest: The authors declare no conflict of interest.

\section{References}

1. Department of Economic and Social Affairs, Population Division. The World's Cities in 2018. Data Booklet; United Nations: New York, NY, USA, 2018.

2. Albino, V.; Berardi, U.; Dangelico, R.M. Smart Cities: Definitions, Dimensions, Performance, and Initiatives. J. Urban Technol. 2015, 22, 3-21. [CrossRef]

3. De Santis, R.; Fasano, A.; Mignolli, N.; Villa, A. Smart City: Fact and Fiction; MPRA Paper; University Library of Munich: Munich, Germany, 2014.

4. Husár, M.; Ondrejička, V.; Varış, S.C. Smart Cities and the Idea of Smartness in Urban Development-A Critical Review. IOP Conf. Ser. Mater. Sci. Eng. 2017, 245, 082008. [CrossRef]

5. Hollands, R.G. Will the real smart city please stand up? City 2008, 12, 303-320. [CrossRef]

6. Battarra, R.; Gargiulo, C.; Pappalardo, G.; Boiano, D.A.; Oliva, J.S. Planning in the era of Information and Communication Technologies. Discussing the label: Smart in South-European cities with environmental and socio-economic challenges. Cities 2016, 59, 1-7. [CrossRef]

7. Cocchia, A. Smart and digital city: A systematic literature Review. In Smart City; Springer: Cham, Switzerland, 2014

8. Dutton, W.H.; Blumler, J.G.; Kraemer, K.L. (Eds.) Wired Cities: Shaping the Future of Communications; G. K. Hall \& Co.: Boston, MA, USA, 1987.

9. Deakin, M.; Allwinkle, S. Urban Regeneration and Sustainable Communities: The Role of Networks, Innovation, and Creativity in Building Successful Partnerships. J. Urban Technol. 2007, 14, 77-91. [CrossRef]

10. Winseck, D. Wired Cities and Transnational Communications: New Forms of Governance for Telecommunications and the New Media. In Handbook of New Media: Social Shaping and Consequences of ICTs; SAGE Publications Ltd.: London, UK, 2002; pp. 393-409.

11. Dameri, R.P.; Cocchia, A. Smart City and Digital City: Twenty years of terminology evolution. In Proceedings of the ITAIS-Italian Conference on Information Systems, Milan, Italy, 15-18 December 2013.

12. Kummitha, R.K.R.; Crutzen, N. How do we understand smart cities? An evolutionary perspective. Cities 2017, 67, 43-52. [CrossRef]

13. Borsekova, K.; Koróny, S.; Vaňová, A.; Vitálišová, K. Functionality between the size and indicators of smart cities: A research challenge with policy implications. Cities 2018, 78, 17-26. [CrossRef]

14. Batty, M.; Axhausen, K.; Giannotti, F.; Pozdnoukhov, A.; Bazzani, A.; Wachowicz, M.; Ouzounis, G.; Portugali, Y. Smart cities of the future. Eur. Phys. J. Spec. Top. 2012, 214, 481-518. [CrossRef]

15. Batty, M. Big data, smart cities and city planning. Dialogues Hum. Geogr. 2013, 3, 274-279. [CrossRef]

16. Kudva, S.; Ye, X. Smart Cities, Big Data, and Sustainability Union. Big Data Cogn. Comput. 2017, 1, 4. [CrossRef]

17. Romanelli, M.; Metallo, C.; Agrifoglio, R.; Ferrara, M. Cities, Smartness and Participation Towards Sustainability; Lazazzara, A., Nacamulli, R.C., Rossignoli, C., Za, S., Organizing for Digital Innovation, Eds.; Springer International Publishing: Cham, Switzerland, 2019; pp. 125-133.

18. Anthopoulos, L.; Janssen, M.; Weerakkody, V. A Unified Smart City Model (USCM) for Smart City Conceptualization and Benchmarking. Int. J. Electron. Gov. Res. 2016, 12, 77-93. [CrossRef]

19. Lee, J.H.; Hancock, M.G.; Hu, M.C. Towards an effective framework for building smart cities: Lessons from Seoul and San Francisco. Technol. Forecast. Soc. Chang. 2014, 89, 80-99. [CrossRef]

20. Neirotti, P.; De Marco, A.; Cagliano, A.; Mangano, G.; Scorrano, F. Current trends in Smart City initiatives: Some stylised facts. Cities 2014, 38, 25-36. [CrossRef]

21. Lazaroiu, G.C.; Roscia, M. Definition methodology for the smart cities model. Energy 2012, 47, $326-332$.

22. Benjelloun, A.; Crainic, T.G.; Bigras, Y. Towards a taxonomy of City Logistics projects. Procedia Soc. Behav. Sci. 2010, 2, 6217-6228. [CrossRef]

23. Benevolo, C.; Dameri, R.P.; D'Auria, B. Smart Mobility in Smart City. In Empowering Organizations; Springer: Berlin/Heidelberg, Germany, 2016; pp. 13-28. 
24. Caragliu, A.; Del Bo, C.; Nijkamp, P. Smart Cities in Europe. J. Urban Technol. 2011, 18, 65-82. [CrossRef]

25. Silva, B.N.; Khan, M.; Han, K. Towards sustainable smart cities: A review of trends, architectures, components, and open challenges in smart cities. Sustain. Cities Soc. 2018, 38, 697-713. [CrossRef]

26. Bakıc1, T.; Almirall, E.; Wareham, J. A Smart City Initiative: The Case of Barcelona. J. Knowl. Econ. 2013, 4, 135-148. [CrossRef]

27. Bibri, S.E.; Krogstie, J. Smart sustainable cities of the future: An extensive interdisciplinary literature review. Sustain. Cities Soc. 2017, 31, 183-212. [CrossRef]

28. Martin, C.J.; Evans, J.; Karvonen, A. Smart and sustainable? Five tensions in the visions and practices of the smart-sustainable city in Europe and North America. Technol. Forecast. Soc. Chang. 2018, 133, 269-278. [CrossRef]

29. Australian Research Council. Excellence in Research for Australia (ERA) 2012 National Report; Technical Report; Australian Government: Canberra, Australia, 2012 .

30. Siddiqi, S.; Sharan, A. Keyword and Keyphrase Extraction Techniques: A Literature Review. Int. J. Comput. Appl. 2015, 109, 18-23. [CrossRef]

31. Kourtit, K.; Nijkamp, P. Smart cities in the innovation age. Innov. Eur. J. Soc. Sci. Res. 2012, 25, 93-95. [CrossRef]

32. Coe, A.; Paquet, G.; Roy, J. E-Governance and Smart Communities. A Social Learning Challenge. Soc. Sci. Comput. Rev. 2001, 19, 80-93. [CrossRef]

33. Paquet, G.; Roy, J. Smarter Cities in Canada through E-Governance; Centre on Governance, University of Ottawa: Ottawa, ON, Canada, 2002.

34. Cosgrove, M. Smarter Cities Series: Introducing the IBM City Operations and Management Solution; IBM Induswtry Solutions Report; IBM Corp.: Armonk, NY, USA, 2010.

35. Zygiaris, S. Smart City Reference Model: Assisting Planners to Conceptualize the Building of Smart City Innovation Ecosystems. J. Knowl. Econ. 2013, 4, 217-231. [CrossRef]

36. Bernardes, M.B.; de Andrade, F.P.; Novais, P.; Lopes, N.V. Reference Model and Method of Evaluation for Smart Cities in Government Portals: A Study of the Portuguese and Brazilian Reality. In Proceedings of the eGose'17 Internationsl Conference on Electronic Governance and Open Society: Challenges in Eurasia, St. Petersburg, Russia, 4-6 September 2017; ACM: New York, NY, USA, 2017; pp. 136-144. [CrossRef]

37. Giffinger, R.; Fertner, C.; Kramar, H.; Kalasek, R.; Pichler-Milanovic, N.; Meijers, E. Smart Cities-Ranking of European Medium-Sized Cities. Final Report; Technical Report; Centre of Regional Science: Vienna, Austria, 2007.

38. Toppeta, D. The Smart City Vision: How Innovation and ICT Can Build Smart, "Livable", Sustainable Cities. Innov. Knowl. Found. 2010, 5, 1-9.

39. Lombardi, P.; Giordano, S.; Farouh, H.; Yousef, W. Modelling the smart city performance. Innov. Eur. J. Soc. Sci. Res. 2012, 25, 137-149. [CrossRef]

40. Perboli, G.; De Marco, A.; Perfetti, F.; Marone, M. A New Taxonomy of Smart City Projects. Transp. Res. Procedia 2014, 3, 470-478. [CrossRef]

41. BSI Standards Publication. Smart Cities_Vocabulary; The British Standards Institution: London, UK, 2014.

42. Ahvenniemi, H.; Huovila, A.; Pinto-Seppä, I.; Airaksinen, M. What are the differences between sustainable and smart cities? Cities 2017, 60, 234-245. [CrossRef]

43. Bibri, S.E. Smart Sustainable Cities of the Future. The Urban Book Series. In Smart Sustainable Cities of the Future: The Untapped Potential of Big Data Analytics and Context-Aware Computing for Advancing Sustainability; Chapter Big Data Analytics and Context-Aware Computing: Characteristics, Commonalities, Differences, Applications, and Challenge; Springer International Publishing: Cham, Switzerland, 2018; pp. 481-533.

44. D'Aniello, G.; Gaeta, M.; Orciuoli, F. An approach based on semantic stream reasoning to support decision processes in smart cities. Telemat. Inform. 2018, 35, 68-81. [CrossRef]

45. Hall, R. The Vision of a Smart City. In Proceedings of the 2nd International Life Extension Technology Workshop, Paris, France, 28 September 2000; pp. 1-6.

46. Kanter, R.; Litow, S. Informed and Interconnected: A Manifesto for Smarter Cities; Harvard Business School General Management Unit Working Paper 09-141. 2009. Available online: https://ssrn.com/abstract= 1420236 (accessed on 22 September 2020). 
47. The ICT Consortium. Smart Communities-The Grand-Challenge Project to Launch the Digital Economy. A Submission to Industry Canada's Digital Economy Strategy Consultation; The ICT Consortium: Ottawa, ON, Canada, 2010.

48. Harrison, C.; Eckman, B.; Hamilton, R.; Hartswick, P.; Kalagnanam, J.; Paraszczak, J.; Williams, P. Foundations for Smarter Cities. IBM J. Res. Dev. 2010, 54, 1-16. [CrossRef]

49. Washburn, D.; Sindhu, U. Helping CIOs Understand "Smart City" Initiatives; FORRESTER: Cambridge, MA, USA, 2010.

50. Chourabi, H.; Nam, T.; Walker, S.; Gil-Garcia, J.R.; Mellouli, S.; Nahon, K.; Pardo, T.A.; Scholl, H.J. Understanding Smart Cities: An Integrative Framework. In Proceedings of the 2012 45th Hawaii International Conference on System Sciences, Maui, HI, USA, 4-7 January 2012; pp. 2289-2297. [CrossRef]

51. Doran, M.A. Villes Intelligentes, Enjeux et Stratégies: Regards Croisés Amérique/Europe/Asie; Institut Technologies de l'Information et Sociétés, Université Laval: Quebec, QC, Canada, 2013.

52. Daniel, S.; Doran, M.A. geoSmartCity: Geomatics contribution to the Smart City. In Proceedings of the 14th Annual International Conference on Digital Government Research: From e-Government to Smart Government, Quebec City, QC, Canada, 17-20 June 2013.

53. Smart City Alliance Alberta. What is the Alberta Smart City Alliance. 2014. Available online: https: / / smartcityalliance.ca/alliance/ (accessed on 15 June 2020).

54. Intelligent Community Forum. From Smart Cities to Intelligent Communities. 2015. Available online: https://www.intelligentcommunity.org/from_smart_cities_to_intelligent_communities (accessed on 5 March 2018).

55. Berst, J.; Logsdon, D. The Hill: At Smart Cities Week, tackling opportunities and challenges. Smart Cities Counc. 2016, 10, 2018.

56. i-Canada Alliance. About I-Canada Alliance. 2016. Available online: http://icanada150.ca/about-i-canadaalliance/ (accessed on 5 March 2018).

57. City of St. Albert. What is a "Smart City"? 2016. Available online: https://stalbert.ca/dev/smart/overview / (accessed on 5 March 2018).

58. The University of British Columbia. Clean Energy Research Center. Smart Cities. Resilient and Intelligent Infrastructure. 2016. Available online: http:/ / cerc.ubc.ca/research/smart-cities/ (accessed on 5 March 2018).

59. City of Surrey. Smart Surrey. 2016. Available online: http://www.surrey.ca/city-government/15430.aspx (accessed on 5 March 2018).

60. Bailey, K.D. Typologies and Taxonomies: An Introduction to Classification Techniques. In Sage University Paper Series on Quantitative Applications in the Social Sciences; Sage Publications: Thousand Oaks, CA, USA, 1994.

61. Bailey, K.D. Typology construction, methods and issues. Encycl. Soc. Meas. 2005, 3, 889-898.

62. European Commission. Smart Cities \& Communities Calls. 2020. Available online: https://ec.europa.eu/ inea/en/horizon-2020/smart-cities-communities (accessed on 15 June 2020).

63. Government of Canada. Smart Cities Community Support Program. 2018. Available online: https://www. canada.ca/en/office-infrastructure/news/2018/06/government-of-canada-launches-the-smart-citiescommunity-support-program-to-help-communities-improve-the-quality-of-life-for-their-residents.html (accessed on 15 June 2020).

64. Smart Cities Council. Web Site. 2018. Available online: https://smartcitiescouncil.com (accessed on 15 June 2020).

65. Mora, L.; Bolici, R.; Deakin, M. The First Two Decades of Smart-City Research: A Bibliometric Analysis. J. Urban Technol. 2017, 24, 3-27. [CrossRef]

66. Perboli, G. GUEST-OR. Linking Lean Business and OR. In Proceedings of the Workshop of the 28th European Conference on Operation Research, Poznan, Poland, 3-6 July 2016.

67. GUEST. The GUEST Initiative Web Site. 2015. Available online: http://www.theguestmethod.com (accessed on 15 June 2020).

68. Osterwalder, A.; Pigneur, Y. Business Model Generation; Wiley John \& Sons: Hoboken, NJ, USA, 2010.

69. Osterwalder, A.; Pigneur, Y.; Bernarda, G.; Smith, A. Value Proposition Design; Wiley John \& Sons: Hoboken, NJ, USA, 2014.

70. Crainic, T.G.; Perboli, G.; Rosano, M.; Wei, Q. Transportation for smart cities: A systematic review. In Proceedings of the 11th International Conference on City Logistics, Dubrovnik, Croatia, 12-14 June 2019. 
71. Cantamessa, M.; Gatteschi, V.; Perboli, G.; Rosano, M. Startups' Roads to Failure. Sustainability 2018, 10, 2346. [CrossRef]

72. Perboli, G.; Musso, S.; Rosano, M.; Tadei, R.; Godel, M. Synchro-Modality and Slow Steaming: New Business Perspectives in Freight Transportation. Sustainability 2017, 9, 1843. [CrossRef]

(C) 2020 by the authors. Licensee MDPI, Basel, Switzerland. This article is an open access article distributed under the terms and conditions of the Creative Commons Attribution (CC BY) license (http://creativecommons.org/licenses/by/4.0/). 